\title{
River-valleys and the Challenges in Hitherto Implemented Projects - A Case Study: Tehran's Seven River-valleys and the Three Linear Parks
}

\author{
Sanaz Shobeiri \\ School of Architecture and the Built Environment, University of Westminster, United Kingdom
}

Copyright $\mathrm{C} 2019$ by authors, all rights reserved. Authors agree that this article remains permanently open access under the terms of the Creative Commons Attribution License 4.0 International License

\begin{abstract}
One of the key challenges in studying the human-nature relationship in urban contexts worldwide is the current issues in hitherto implemented projects. The term 'issues' here refers to the needs, potentials and problems of the two spheres of citizens and the city's natural structures. Investigating the present issues in implemented projects reveals how people perceive and subsequently interact with the nature in cities at the present time. This paper aims to open up a research platform in order to revive, improve and strengthen the human- nature interaction in current and future projects. To this end, Tehran and its seven river-valleys have been selected as the case study for this research. Three linear parks and four mountainous recreational areas are the principal projects that have been implemented along specific lengths of some of the seven main river-valleys in Tehran. This paper focuses mainly on the interaction of Tehranian residents with the natural structures of the river-valleys in the three implemented linear parks. The applied methodology consists of a literature review, followed by related analysis and direct observation. The findings are categorised into seven sections: dealing with height differences and a definition of the horizontal layers; physical perceptions of the river; physical perceptions of the height difference; bridges over the river; facilities; lighting; and accessibility and parking spaces. As the main conclusion, this paper will introduce the design and planning strategies and objectives that could improve the possibility and quality of the human-nature interaction in current and future linear parks in the river-valleys of Tehran.
\end{abstract}

Keywords Linear Parks, Human Beings, Nature, Natural Structures, River-valleys, Tehran

\section{Introduction}

Ecological studies, landscape design, urbanism, sociology, anthropology, cultural studies, psychology and neuroscience are just a few examples of the different fields in which the human-nature relationship has been studied from a variety of perspectives. This paper mainly studies the existing and potential issues in the human-nature relationship in the projects that have been implemented to date. With a specific focus on Tehranian residents and Tehran's seven river-valleys, this research investigates the present and future needs, problems and potentials of rivervalleys, as well as those of Tehranian users in the current projects.

To this end, it is necessary to identify and review the literature on the previously implemented projects. Reviewing these works shows that, to date, three parks and four recreational projects have been implemented in specific areas of the seven main river- valleys of Tehran. However, no previous study has investigated how Tehranian residents interact with the existing natural structures of the river-valleys in these projects. This paper focuses mainly on the three aforementioned linear parks. The method of direct observation is used in the current research to study the present interaction of Tehranians and the river- valleys in the linear parks. In other words, the paper critiques the contemporary (mis)management of the river- valleys in Tehran through direct observation.

The findings from the direct observation are categorised into seven sections: dealing with height differences and a definition of the horizontal layers; physical perceptions of the river; physical perceptions of the height difference; bridges over the river; facilities; lighting; and accessibility and parking spaces. Numerous physical factors have played a significantly role in forming the interaction between Tehranians and Tehran's river- valleys and, hence, have affected and shaped Tehranians' perceptions of these natural structures. However, these seven factors are highlighted in this study as they have more intense effects and a stronger influence in the present interaction. This point has been revealed through direct observation in 
the parks and mountainous areas.

The conclusion section of this paper discusses how the seven aforementioned factors need to be altered in order to improve the human-nature relationship in the implemented projects of the three linear parks. The proposed characteristics of these seven factors can also be reflected in the design and planning processes for future projects within the seven river-valleys of Tehran. The conclusion section also opens the possibility of a debate for future studies in the field of landscape design in terms of the relationship between environmental sustainability and other aspects of sustainability such as social and cultural.

\section{Methodology}

\subsection{Literature Review and Related Analysis}

Since the focus of this research is the city of Tehran, a detailed study of the interaction between Tehranian residents and the city's seven major river-valleys is necessary. In other words, in order to study the humannature interaction in Tehran, it is necessary to review the literature relating to the city of Tehran, specifically the gradual and drastic changes that the city has undergone since becoming the capital in 1794. This review clarifies the detailed characteristics of the context and, hence, illustrates the chronological process of the changes that have taken place in the structure and form of Tehran and its seven river-valleys.

As explained by Finn [1] in 2005, a critical evaluation is carried out through the process of revising and updating the literature review at different stages of the research. This results in providing in-depth information on the context and background of the study. As further explained in the book Architectural Research Methods by Groat and Wang [2] in 2002 , a review of the literature is also helpful to identify the research question, focus the topic of inquiry, understand the make-up of the research question and understand the current conceptual landscape. This led to modification of the research question in this paper during the research process in order to cover the cultural, historical and environmental aspects of sustainability [2].

\subsection{Direct Observation}

As explained above, in order to investigate the present and future needs, potentials and problems of the rivervalleys and the Tehranians' issues, it is necessary to identify and review the executed projects within the seven major river-valleys of Tehran. This review shows that three linear parks and four mountainous recreational designs have been implemented in specific areas of the seven main river-valleys of Tehran. The literature review of these parks and mountainous areas clarifies the general characteristics of the executed projects. However, no previous study has been carried out on the interaction between Tehranian residents and the existing natural structures of the rivervalleys in these projects. Addressing this gap in the literature necessitates the use of a complementary method. Accordingly, this research uses direct observation to investigate the present and future potentials and problems of Tehranians and the river-valleys.

Qualitative-based analysis through direct observation is ' $\ldots$ an interpretive naturalistic approach to its subject matter ... [it studies] things in their natural settings, attempting to make sense of, or interpret, phenomena in terms of meanings people bring to them' $[2, \mathrm{p} .176]$. The focus on natural settings in the method of direct observation results in studying the non-interfered status [2]. Hence, in this paper, the actual needs, potentials and problems associated with the interaction between Tehranians and the river-valleys are studied in their usual and ordinary status through direct observation. All of the photos presented in the findings from the direct observation were taken by the researcher, unless stated otherwise.

In order to consider the possible seasonal effects in this research, direct observation was carried out mainly in the seasons of spring, autumn and winter of 2012 and 2013. This appraisal was carried out at different times during the day, from $10 \mathrm{am}$ to $2 \mathrm{pm}$ and $6 \mathrm{pm}$ to $1 \mathrm{am}$. Although the linear park areas are used throughout the day from around $7 \mathrm{am}$ to $2 \mathrm{am}$, these areas become more crowded in the hours specified above. This point was revealed in the preliminary two weeks of direct observation in the first case study of the park named Javanmardan-e-Iran Park in the summer of 2012. The reason for the presence of more people at specific hours of the day relates mainly to the activity patterns of these areas.

\section{The Context: Tehran}

Tehran has been the capital of Iran since 1794. Since then, it has experienced three historical eras: the Qajar dynasty (1794-1925), the Pahlavi dynasty (1925-1979), and the Islamic Republic (1979-present). Throughout these years, the entire area of the city has undergone constant development. The structural and spatial changes to Tehran, particularly since the city became the capital, have resulted in the transformation of an enclosed city; its population has increased from 15,000 in 1794 to a provincial total of 13 million in 2017, as it has developed into a megalopolis[38]. It would be beyond the scope of this paper to outline the full details of all dynasties and events related to all of the kings of Iran; however, the following diagrams describe in more detail the key dynasties and the kings who promoted changes in Tehran, as well as the central points in the process of the city's development and expansion. 

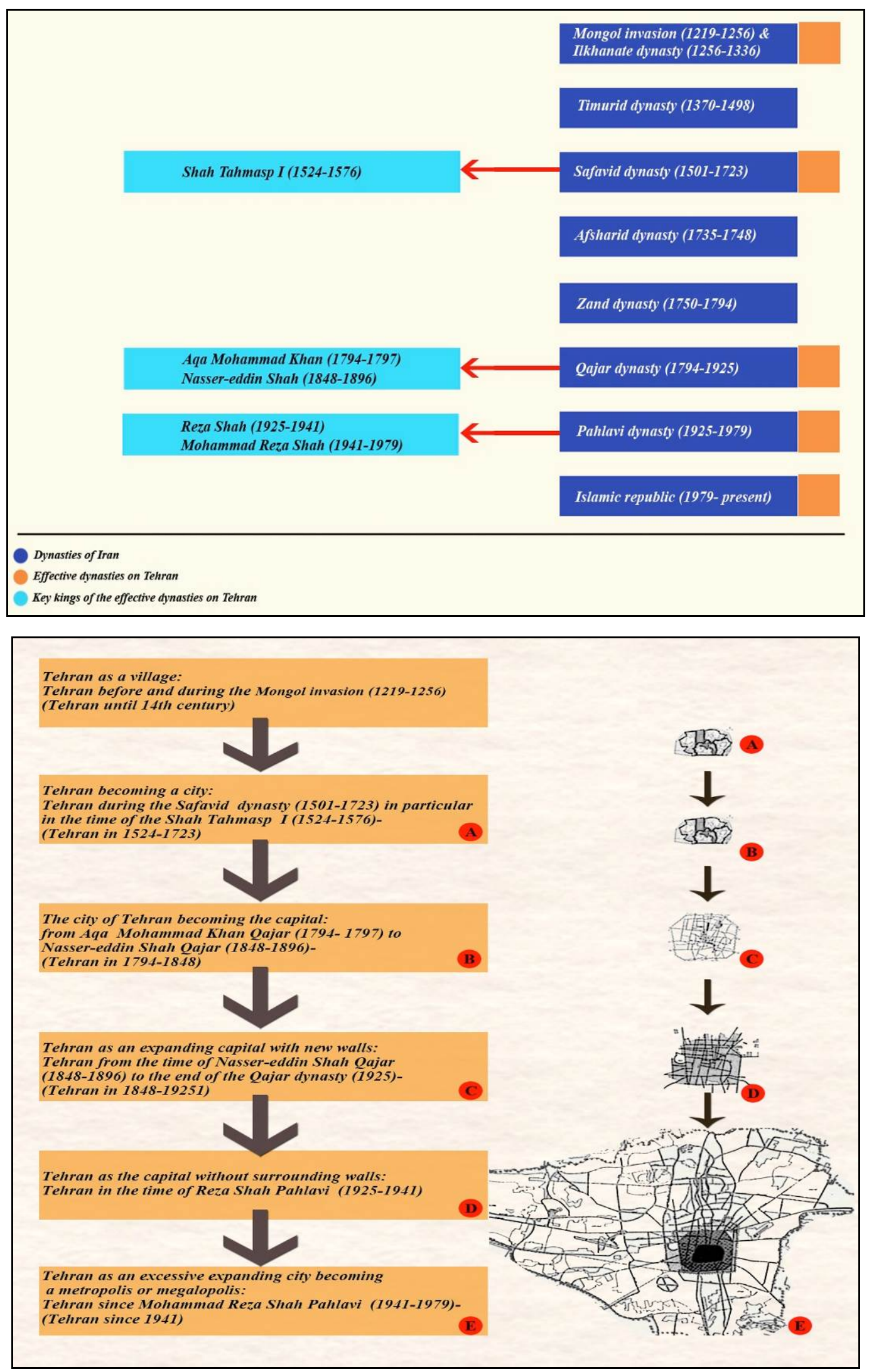

Figure 1. (Top) The most relevant dynasties and kings in the process of change in Tehran (Source: Author, 2016). (The sources for this diagram are References $[3-6,9,10]$. It should be noted that, during the Afsharid and Zand dynasties, minor changes were made to various resources. However, the most important dates are mentioned in the diagram.); (bottom) Tehran and its developments and expansion (Source of the maps: References [4,5]; Source of the applied dates: References [3-6,9,10]) 


\section{Tehran's Seven River-valleys}

Tehran has seven major river-valleys; however, there are various opinions on the total number of river-valleys in Tehran (for further details, please see References [11-15]). From the easternmost to the westernmost areas of Tehran, these seven main river-valleys are called Sorkheh Hesar, Dar Abad, Darband, Evin-Darakeh, Farahzad (Pounak), Hesarak and Kan[11-13]. Since Tehran has a slope in the north-south direction, these river-valleys are mostly parallel, specifically in the northern half of the city. This topography causes water to flow from north to south [15, 16]. The locations of these seven river-valleys are shown below.

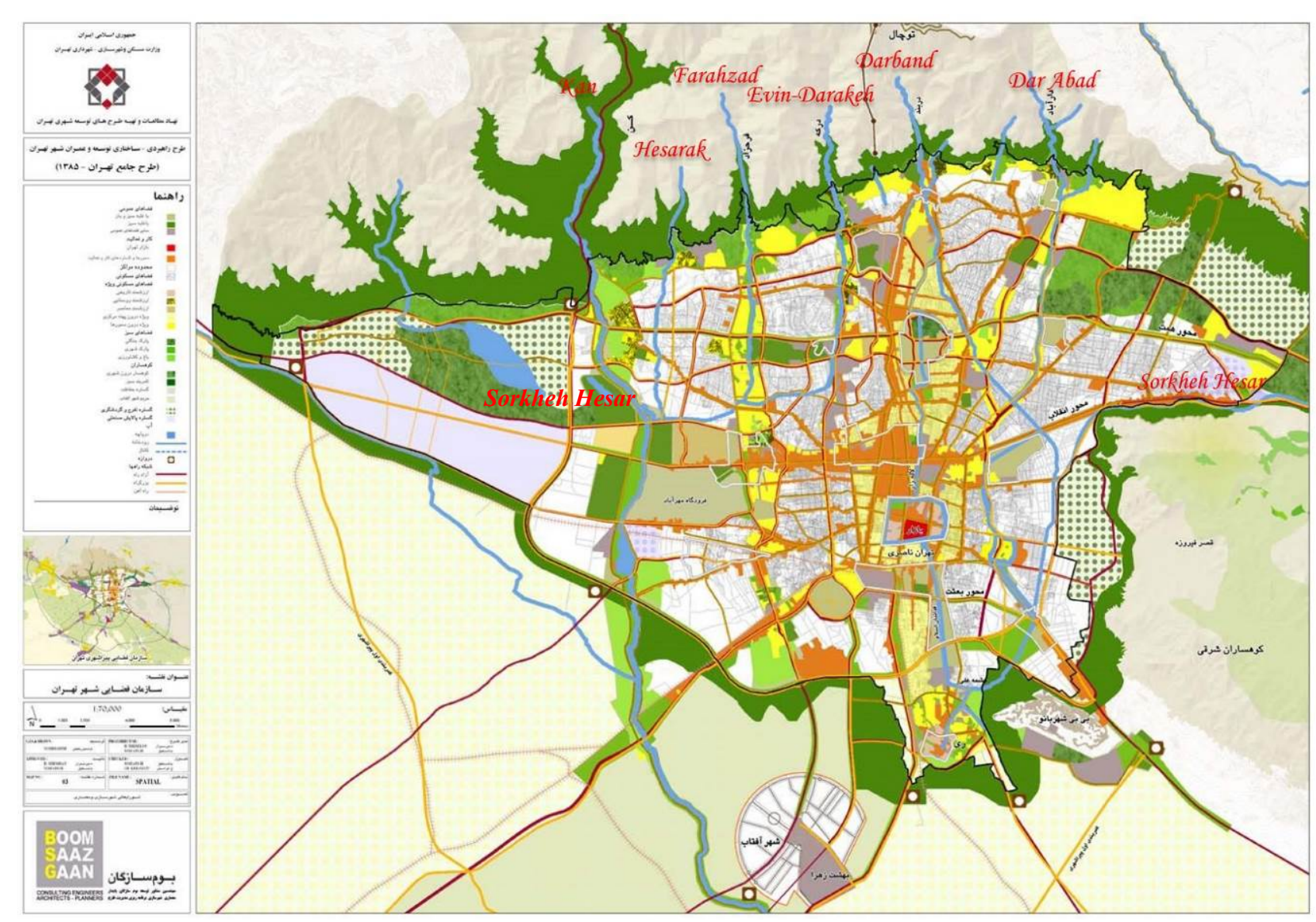

Figure 2. Location of the seven river-valleys in the spatial structure of Tehran (Source: Reference [15])

In addition to the seven principal river-valleys, there are also other minor river-valleys of shorter lengths or with lower volumes of water. As explained by Behzadfar [11] in 2007, Tehran has thirteen river-valleys, of which seven can be described as major. The minor rivers reach the principal rivers at specific points, resulting in an increase in the water volume and the formation of junctions. This phenomenon could cause a synthesis of potentials and problems. The locations of the major and minor rivers, as well as the locations of the confluences, are shown in the map below. An example photo of one of the junctions is also presented here to show the formation of synthesis at junctions. 

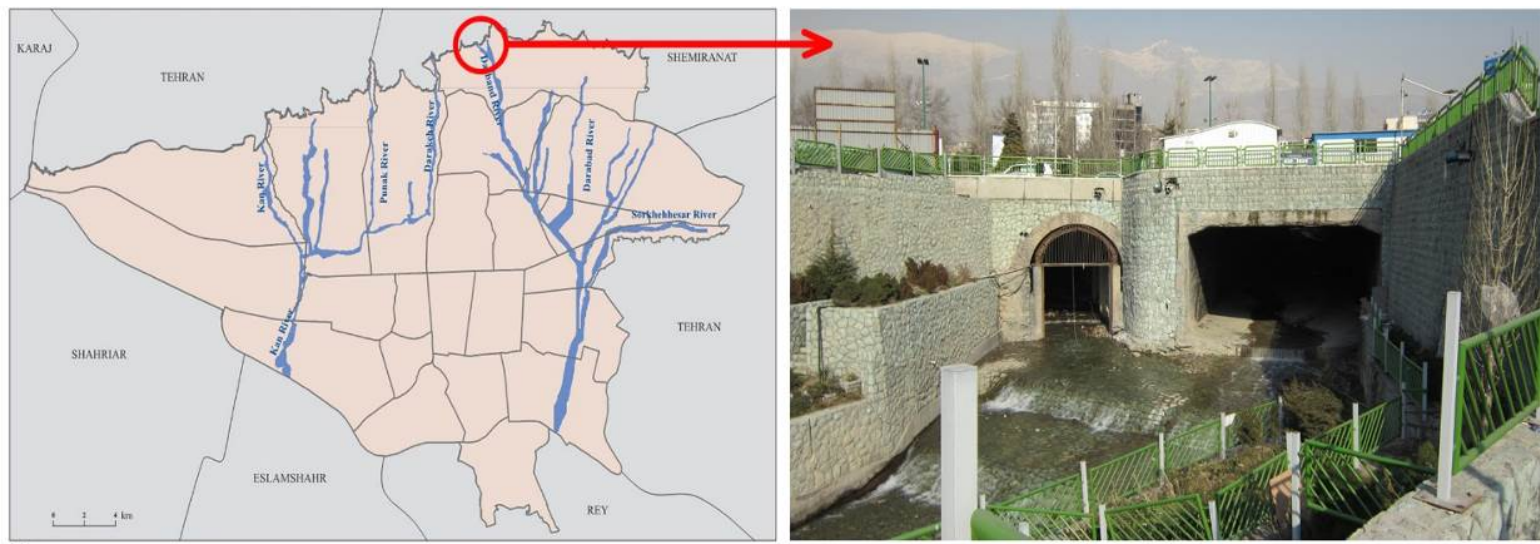

Figure 3. (Left) Minor and major rivers of Tehran (Source: Reference [14]); (right) the junction of the two rivers, Golab-Darreh and Darband, in the northern area of Tehran (2012) (Source: Author, 2012)

Geographically, Tehran has a special position. Located at the southern slopes of the Alborz Mountain, this city has rich resources of water and a mild climate. The slopes of Alborz provide natural protection against the heat and dryness of the southern deserts. Considering the topography of Tehran, the height difference between the northernmost and southernmost areas reaches around $1 \mathrm{~km}$. In this range of height in the north-south direction, the city consists of three sections, including the mountain, foothills (hillsides) and the plain lands. This height difference creates visual corridors towards the mountains in different parts of the city. Although the height decreases in the north-south direction, there are some semi-mountainous areas in the southeast neighbourhood area of Tehran, called Bibi Shahr Banoo Mountain [11, 12, 17-19].

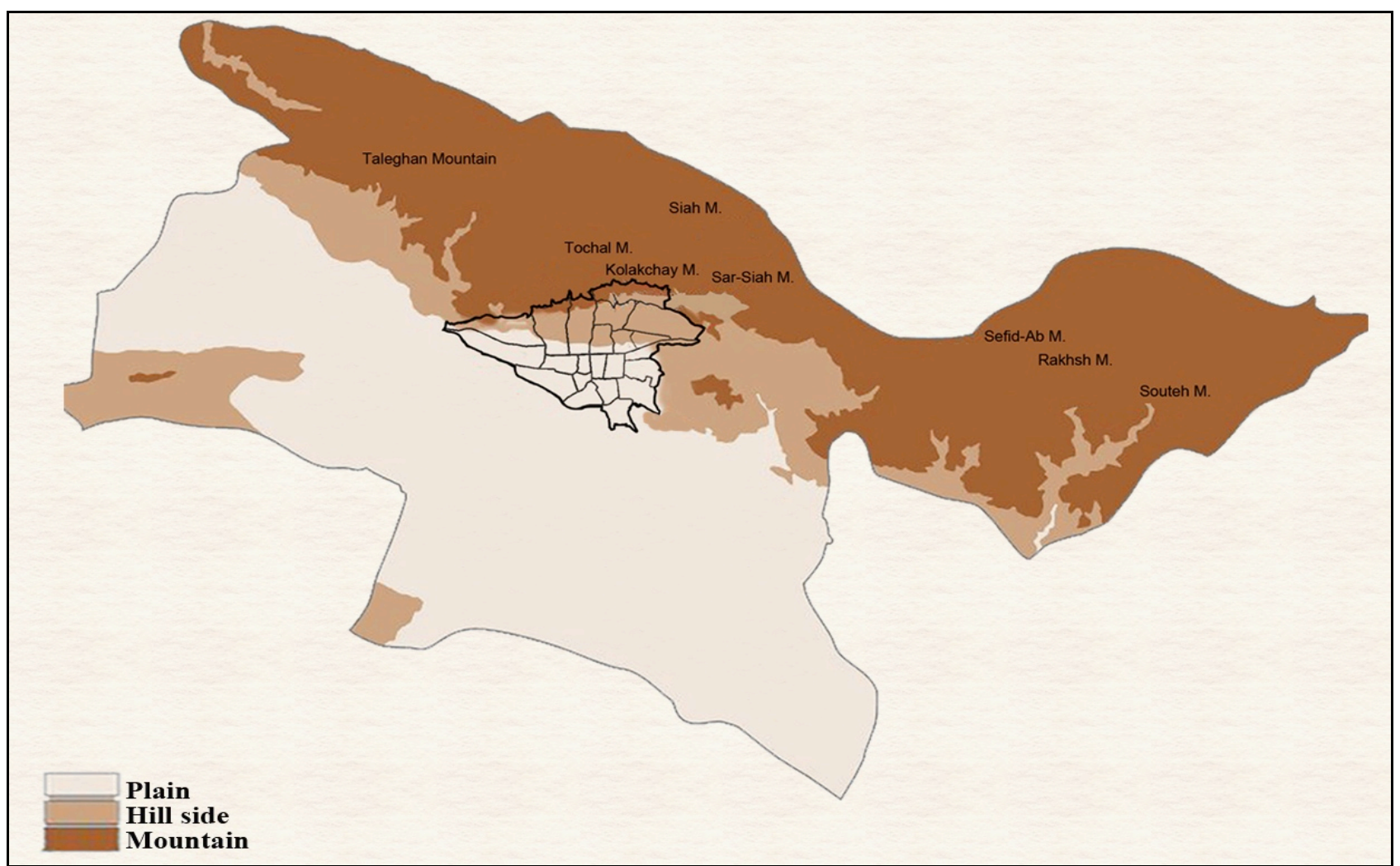




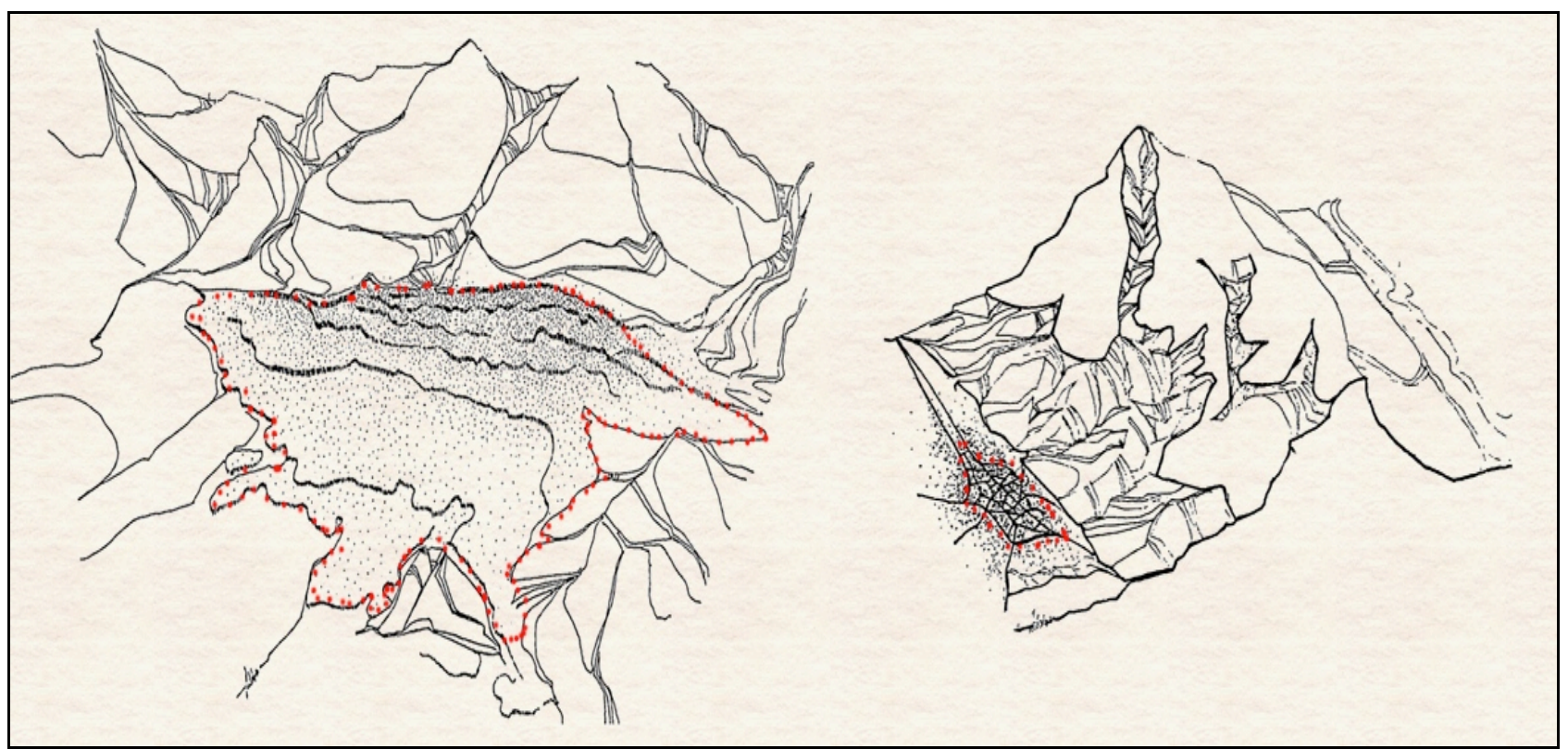

Figure 4. (Top) Topography of Tehran province (2006) (Source: Reference [14]); (bottom) Tehran is located on the slopes of the Alborz mountain (located in northern Tehran) (Source of the base map: Reference [12])
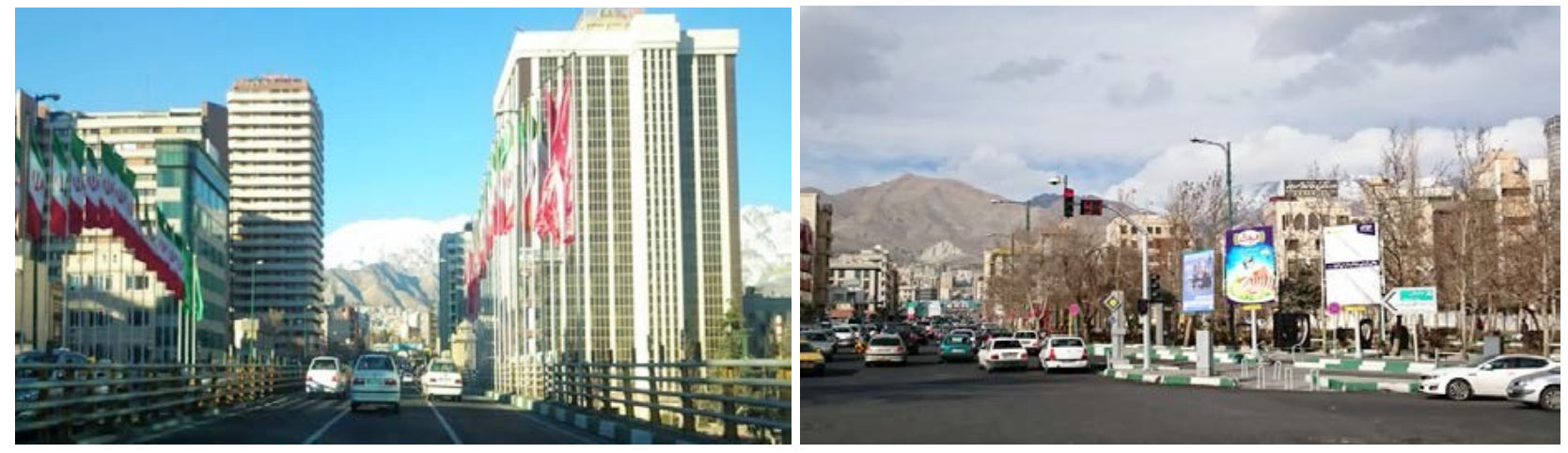

Figure 5. Examples of the visual corridors facing the mountains of North Tehran (2015) (Source: Author, 2015) 


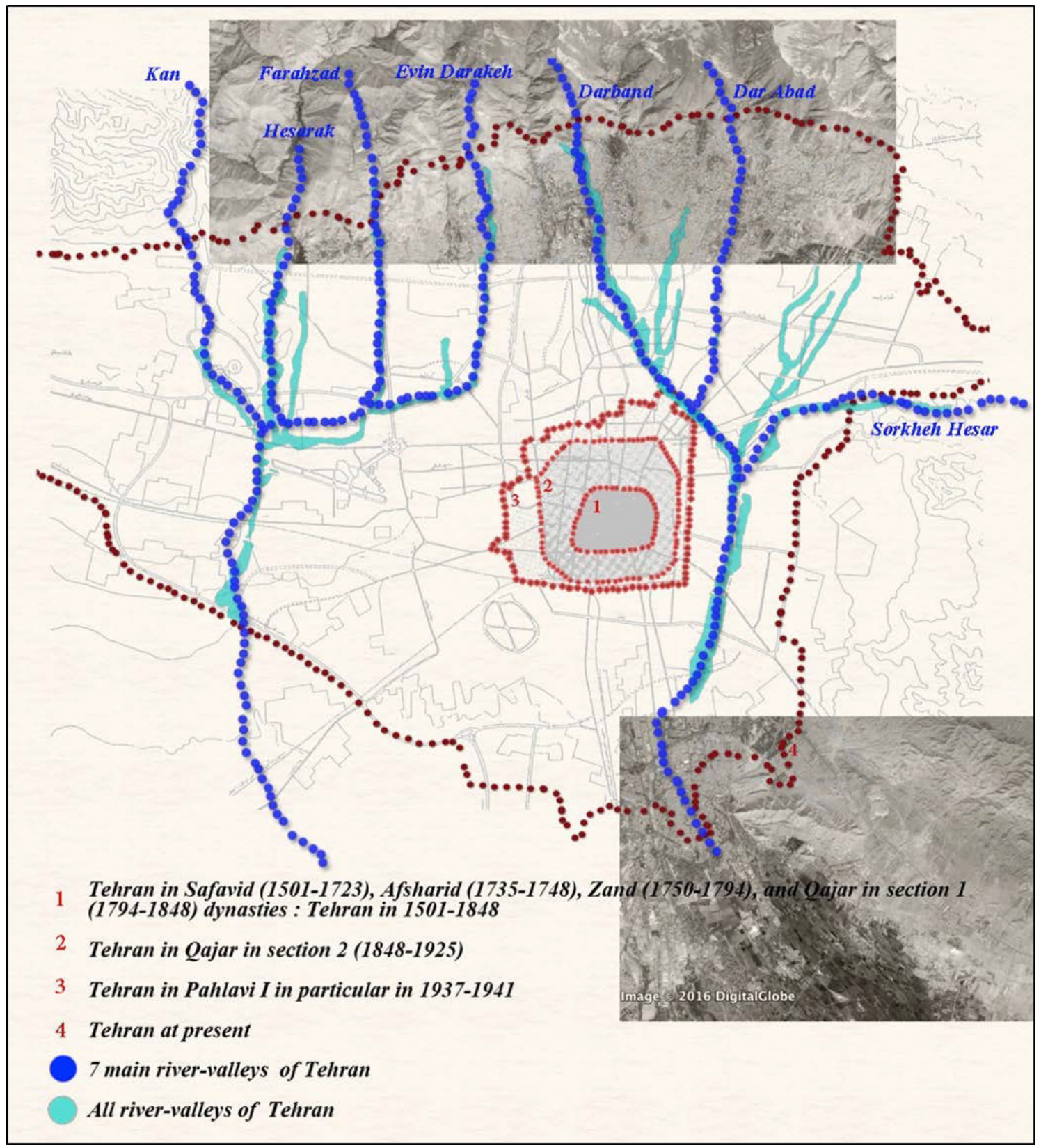

Figure 6. Present-day Tehran and the process of the city's expansion since the Safavid dynasty, and the locations of all river-valleys in Tehran (Source of the base maps: References [11-15, 20-23])

\section{Introduction of the Three Linear Parks and the Three Mountainous Recreational Areas}

The implemented projects on the seven major rivervalleys of Tehran include three linear parks and four mountainous recreational areas. The three linear parks, which were created by the Municipality of Tehran, are situated along the short lengths of three of the seven rivervalleys. These projects include Park-e-Saheli, or Riparian Park, on the Dar Abad river-valley in district 1 of Tehran, Nahj-ol-Balagheh Park on the Farahzad river-valley in district 2, and Javanmardan-e-Iran Park on the Kan river- valley in districts 5 and 22 .

In addition to these three linear parks, there are four recreational areas in the mountainous and semi-urban parts of four of the river-valleys, at Dar Abad, Darband, EvinDarakeh and Farahzad. These recreational areas are mostly used for mountaineering, hiking and other leisure activities by Tehranians as well as tourists. Dar Abad, Darband and Evin-Darakeh recreational areas are located in district 1 of Tehran, while Farahzad recreational area is situated in district 2[13,21-23]. The three aforementioned linear parks are studied in this paper. The locations of all these projects within Tehran and corresponding photos are presented in the following figures (Figures 7 and 8). 

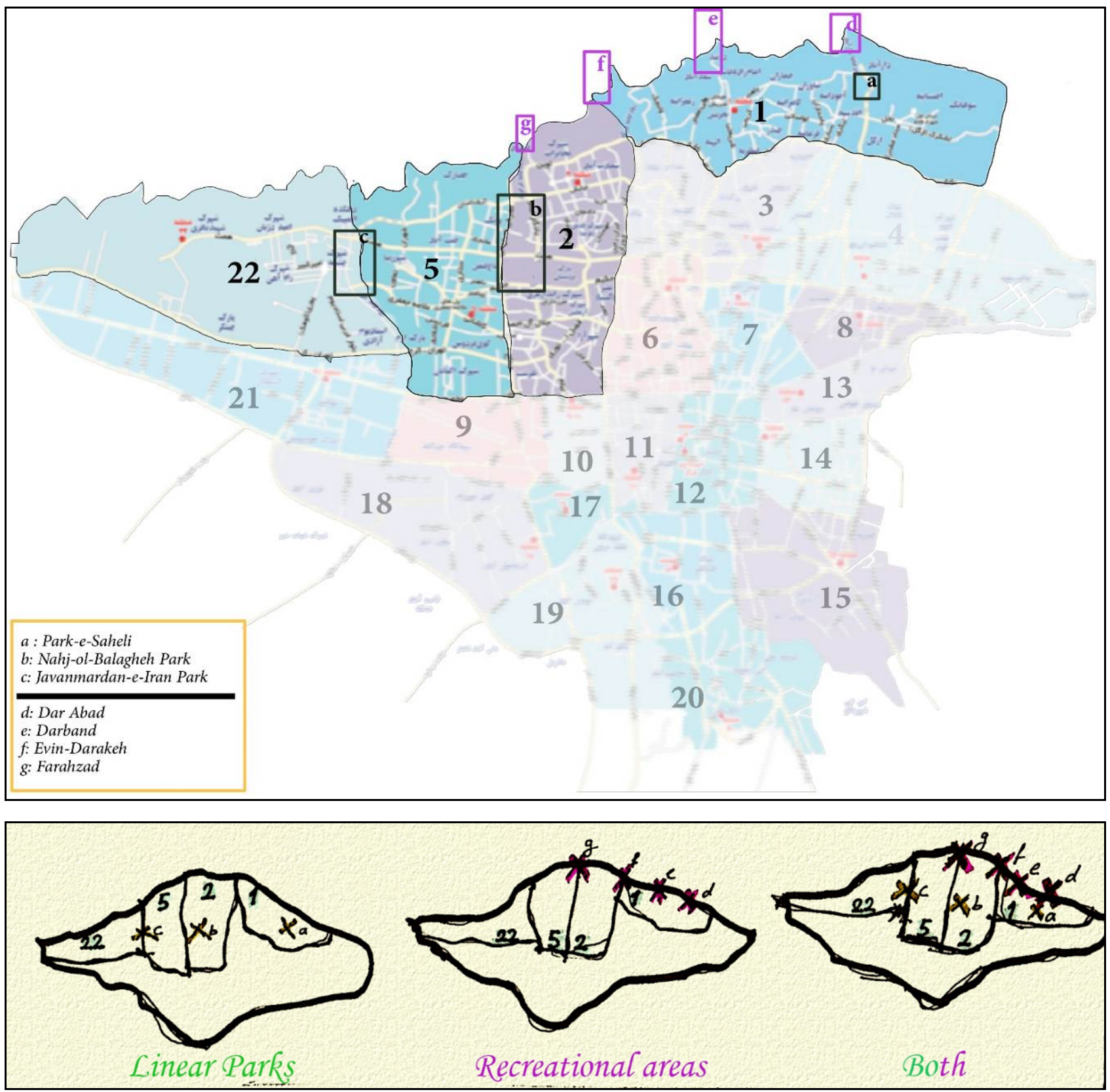

Figure 7. (Top) Locations of three linear parks and four mountainous recreational areas in Tehran (Source of the base map: Reference [21]); (bottom) diagram showing the location of three parks and four mountainous recreational areas (Source: Author, 2012) 


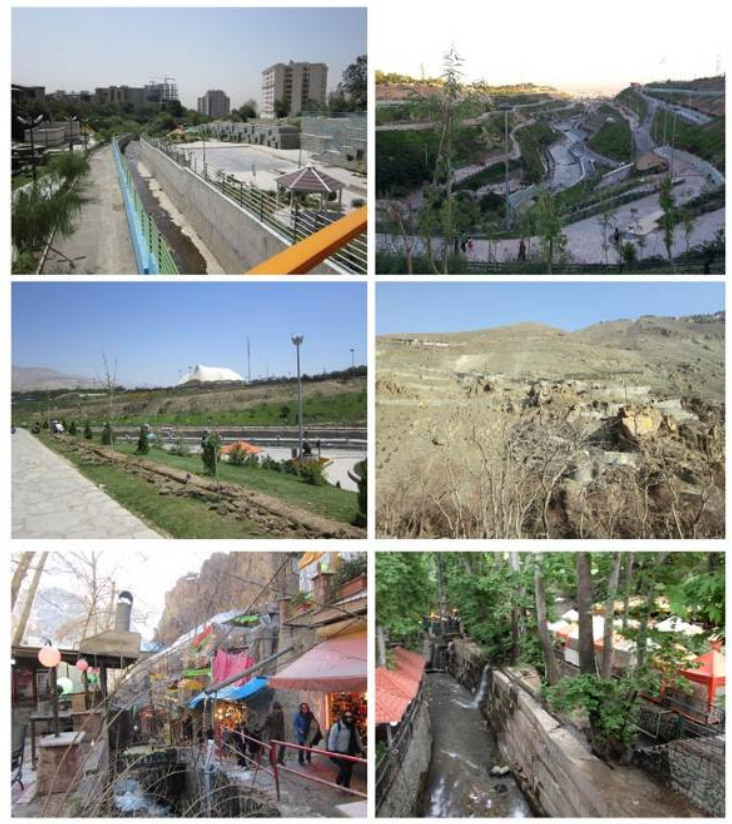

Figure 8. Hitherto implemented projects in the form of linear parks and mountainous areas (2012-2013): (top left) Park-e-Saheli project in Dar Abad; (top right) Nahj-ol-Balagheh Park in Farahzad (phase 2); (middle left) Javanmardan-e-Iran Park in Kan; (middle right) Dar Abad mountainous area; (bottom left) Darband mountainous recreational area; (bottom right) Evin-Darakeh mountainous recreational area (Source: Author, 2012-2013)

\section{Construction, Development Process and Exact Location}

\subsection{Park-e-Saheli}

The construction of Park-e-Saheli in the Dar Abad rivervalley began in 2010 . The development process for the first phase of this park (3 hectares) was completed in 2014. In 2012, 1.6 hectares were opened to the public. Since the completion of the first phase, the development project for the second phase, with a total space of 4 hectares, has been considered in the five-year plan of the municipality, specifically the Municipality of district 1[22]. The section of Dar Abad River in this park is polluted due to the presence of two hospitals and one garbage transit point nearby.

The Municipality of district 1 has, indeed, created this park to provide a solution for the high level of pollution and to protect the natural environment of the area. However, river pollution is still one of the main problems of this park. This issue is further explained in the following sections. The Park-e-Saheli project is located in the west part of Hashemi Street, between the two hospitals, Masih Daneshvari (hospital and National Research Institute of Tuberculosis and Lung Diseases) and Artesh (army) hospital [22].
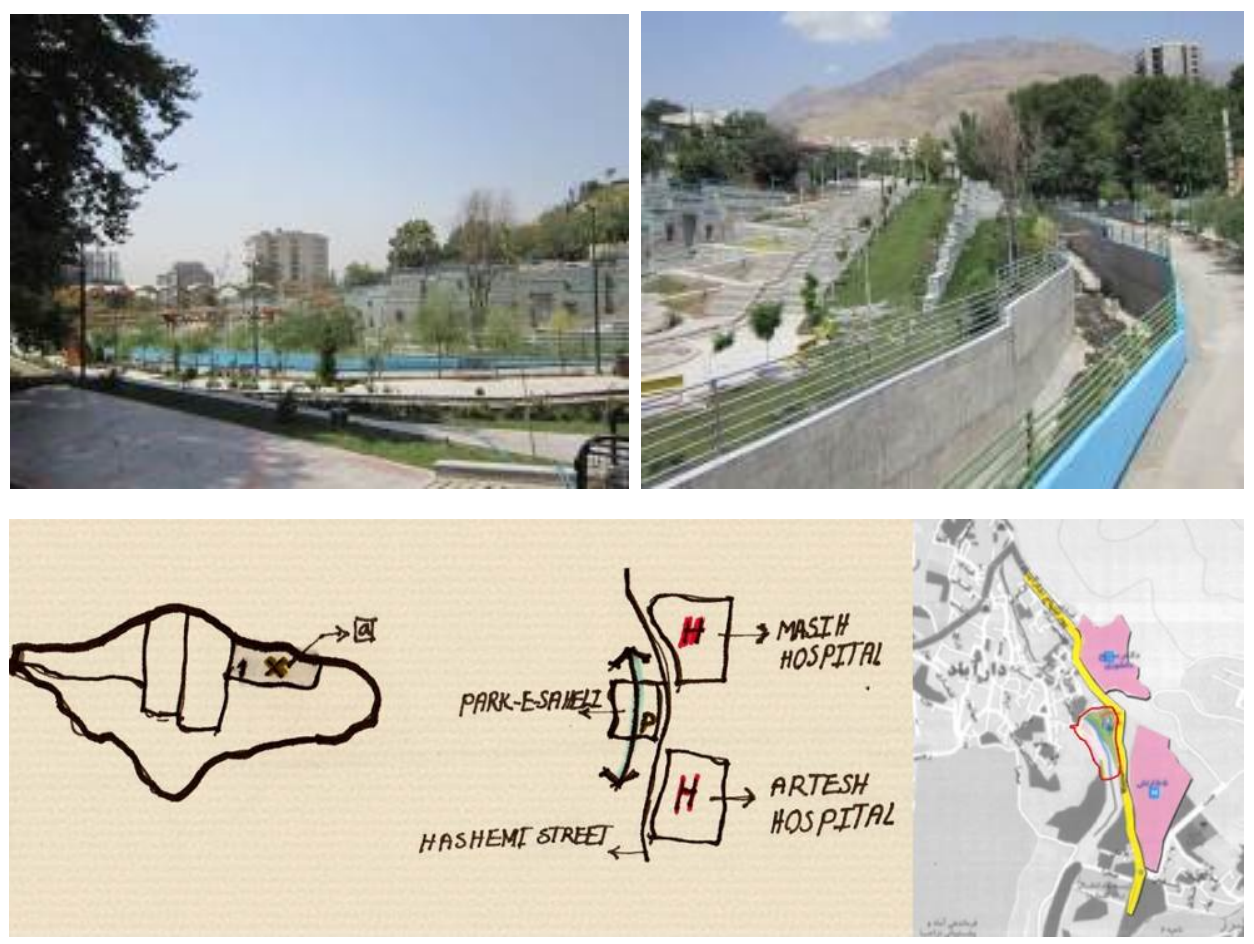

Figure 9. (Top) Different views of the Park-e-Saheli project in the Dar Abad river-valley (2013) (Source: Author, 2013); (bottom) location of the Park-e-Saheli project in the Dar Abad river-valley (Source of the bottom- left image: Author, 2013; Source of the base map in the bottom-right image: Reference [22]) 
Dar Abad is an urban quarter in the northeast of Tehran. Before the Islamic revolution in Iran in 1979, Dar Abad was known mainly as a village on the hillside of Alborz Mountain. The history of this quarter goes back 250 years, when the fifth king of the Qajar monarchy in Iran, Mozaffareddin Shah (1853-1907), was suffering from tuberculosis, and thus ordered the construction of a palace in an area with a mild climate. In those days, Dar Abad village was well known for its vast agriculture and animal husbandry and thus it was chosen for this purpose. Later, in the era of King Reza Shah Pahlavi (1925-1941), more buildings were added to the palace and it was transformed into a hospital for tuberculosis and lung diseases. This hospital still exists and is called Masih Daneshvari today [22-27].

\subsection{Nahj-ol-Balagheh Park}

Nahj-ol-Balagheh Park is located in the Farahzad rivervalley and was constructed by the Municipality of district 2 . The first phase of this park, with a total space of 35 hectares, was opened to the public in 2010. The second phase, with a space of 45 hectares, was opened to the public in May 2013[28]. As the date of completion of this project shows, phase 2 of this park was completed after the start of this research in 2011.

Before the opening of this park, the neighbourhood was suffering from several major problems - such as river pollution, security problems and an increasing number of drug addicts - that necessitated an urgent decision by the municipality $[28,29]$. It should be noted that phase 1 of Nahj-ol-Balagheh Park is located between two streets, Hamila Blvd (north) and Hemmat highway (south). Phase 2 of this park is located between two highways, Hemmat (north) and Hakim (south).

\subsection{Javanmardan-e-Iran Park}

The first phase of Javanmardan-e-Iran Park in the Kan river-valley was completed between 2010 and 2012 and was opened to the public in July 2012. The second and third phases of this project are still under implementation. The first phase deals with 66 hectares of space in districts 5 and 22 (36 hectares in district 22 and 40 hectares in district 5). The first phase of this linear park is located between two highways, Hemmat (north) and Hakim/Resalat (south), and is in the boundary area of districts 5 and 22[31].
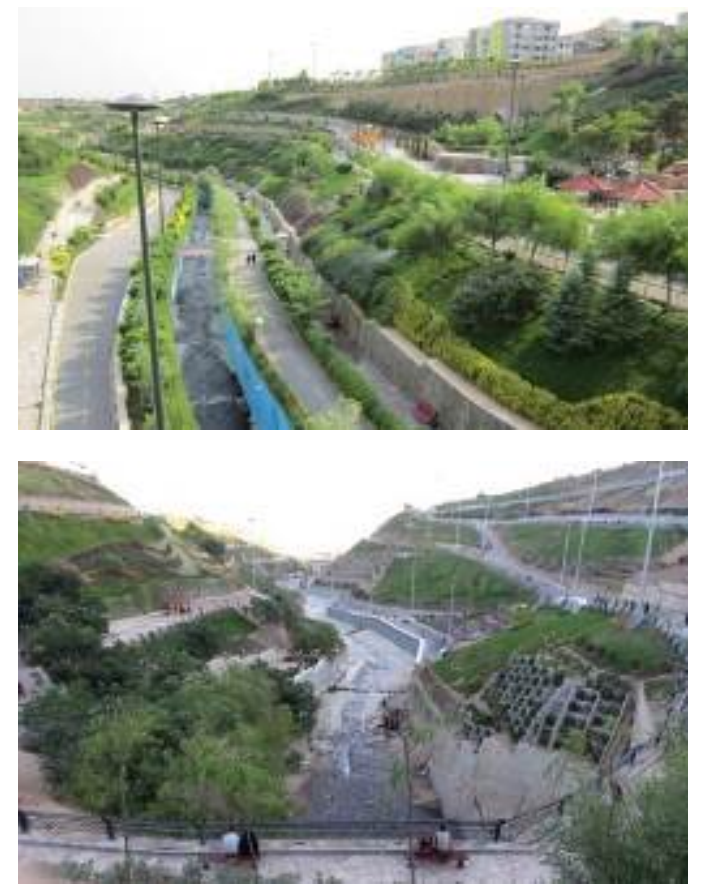

Figure 10. Nahj-ol-Balagheh Park in Farahzad: (left) Phase 1 (2012); (right) Phase 2 (2013) (Source: Author, 2012-2013)

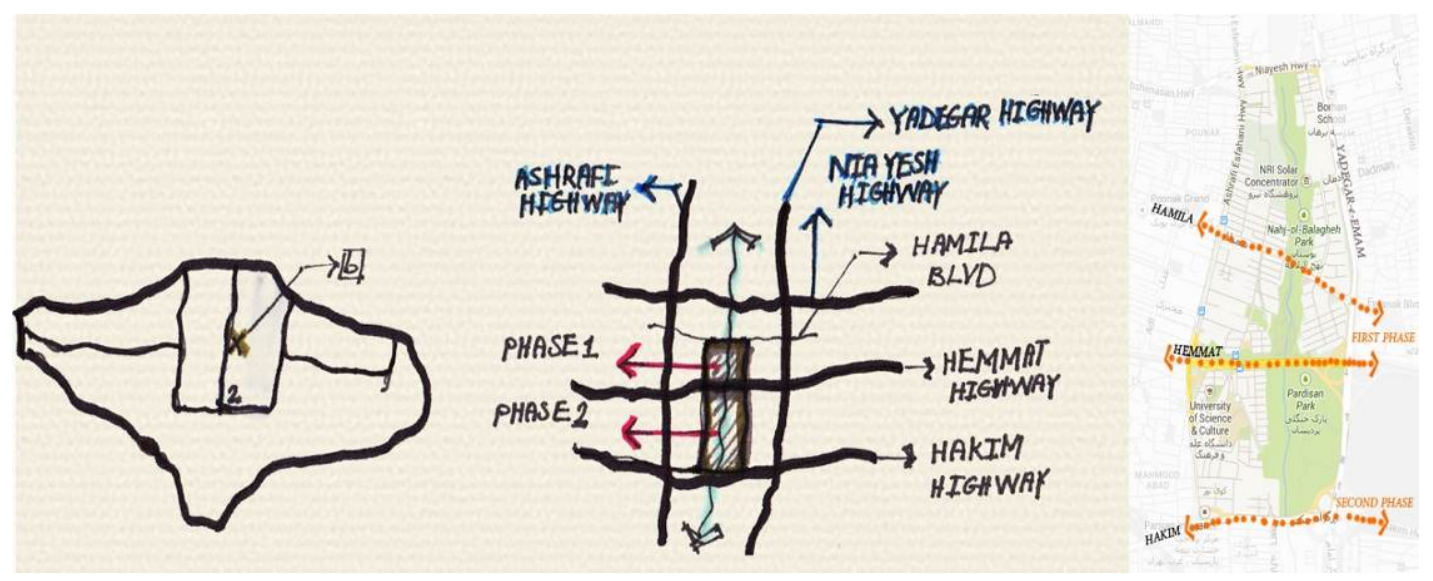

Figure 11. Location of Nahj-ol-Balagheh Park in the Farahzad river- valley (Source of the left image: Author, 2013; Source of the base map in the right image: References [22, 30]) 

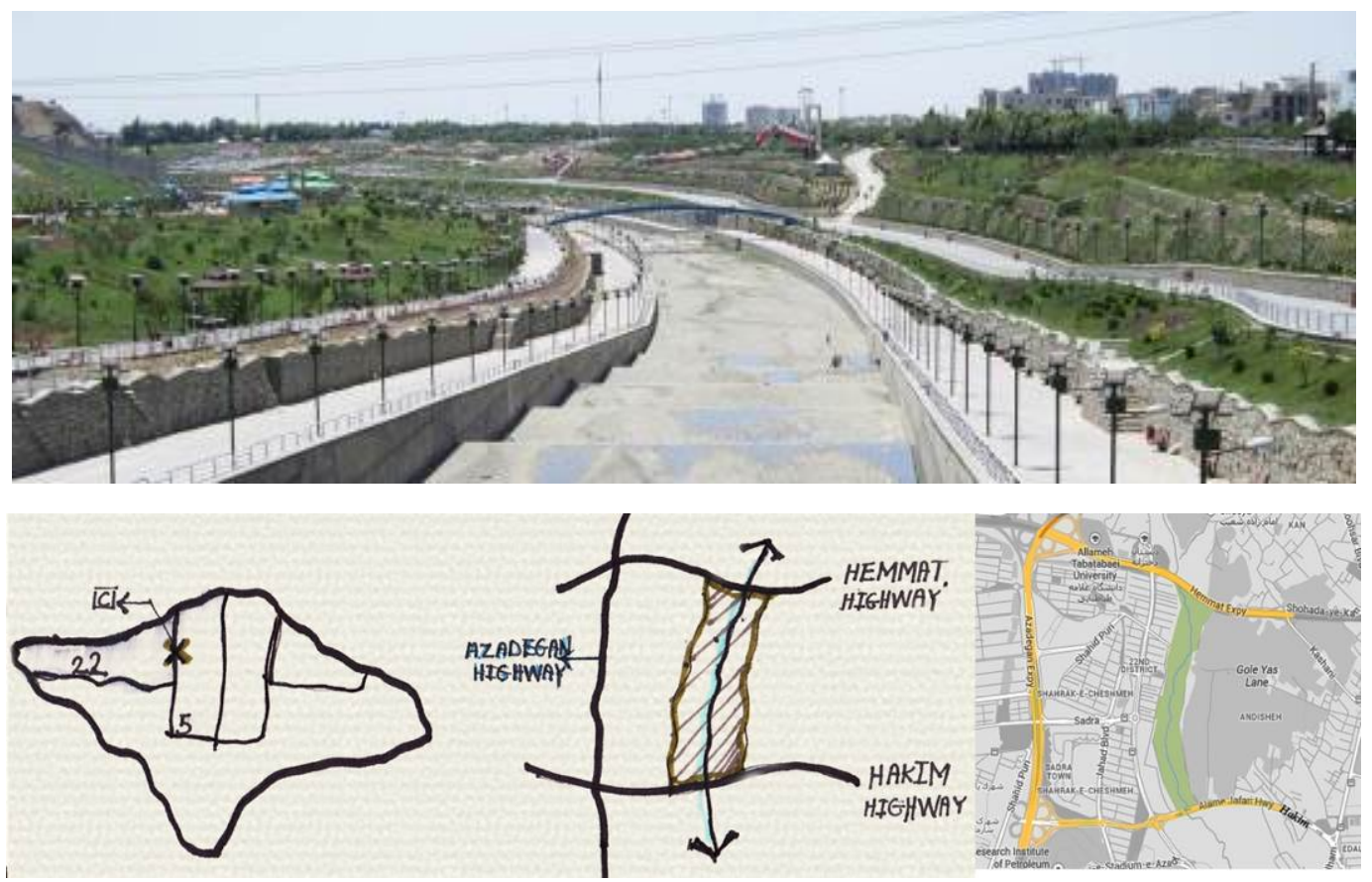

Figure 12. (Top) Javanmardan-e-Iran Park in Kan river-valley (2012) (Source: Author, 2012); (bottom) location of Javanmardan-e-Iran Park in the Kan river-valley (Source of the bottom-right image: Author, 2012; Source of the base map in the bottom-right image: Reference [31])

A general description of the three parks has been presented based on the review of the related literature and analysis. The following sections present the findings of the direct appraisal method with regard to the key issues of the linear parks. The key issues in the following sections include height difference and definition of horizontal layers, physical perceptions of the river, physical perceptions of the height difference, bridges over the river, facilities, lighting, accessibility and parking spaces.

\section{Height Difference and Definition of Horizontal Layers}

Direct observation in the three linear parks revealed that citizens' preferred activities are affected by the way they perceive the dimensions of an area. Therefore, a key factor to study in the context of linear parks is how the design of these places shapes one's perception of their dimensions. It is thus necessary to study how the defined dimensions in the implemented projects are perceived by Tehranian users. Height difference and definitions of horizontal layers are studied here in order to investigate in detail the relationship between users' perceptions of the applied dimensions and users' preferred activities in the three linear parks.

\subsection{Park-e-Saheli}

In the Park-e-Saheli project, vertical layers of decorative stone walls have been applied to deal with the height difference within the river-valley. In order to connect the two major horizontal layers, many stairs (a total number of
50) have been built alongside the river throughout the park. This layout makes it difficult to access the different areas of the park, and thus makes the park less usable for people with disabilities or mobility difficulties, the elderly and families with young children. Furthermore, since only two major horizontal layers exist in this park, the variety of activities alongside the river has been limited to hiking.

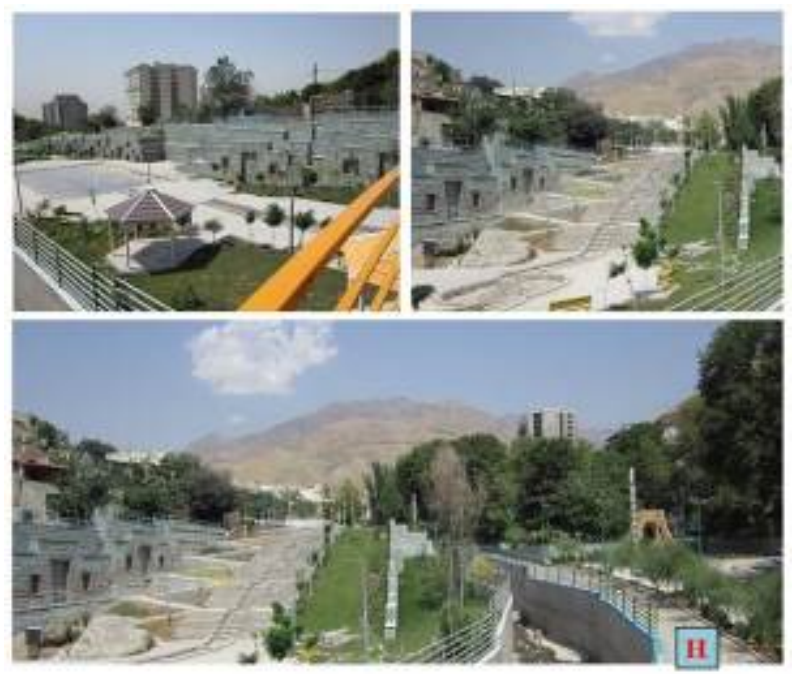

Figure 13. Park-e-Saheli project (2013): (left) decorative stone walls; (right) the stairs; Park-e-Saheli project (2013): hiking path (H: hiking) (Source: Author, 2013)

\subsection{Nahj-ol-Balagheh Park}

In Nahj-ol-Balagheh Park, the application of different horizontal layers - from the river level at the lowest point 
of the river-valley to the highest point - makes it possible for visitors to experience various perspectives while walking on the hiking paths or cycling at different height levels. Layers at different height levels allow users to select their preferred height layer at which to spend more time on their preferred outdoor activities. Eating dinner with family members and taking part in favourite sports are examples of such activities. The horizontal layers of the different height levels are also used as recognisable paths for different activities such as hiking, cycling and skating.

Defining separate linear paths at different height levels for sports such as hiking, cycling and skating makes it possible for one to experience various perspectives while enjoying preferred activities. However, in order to ensure safety, there should be clear boundaries between these activities [23]. In phase 1 of Nahj-ol-Balagheh Park, the intersection point of the hiking and cycling paths at the entrance of the park is not well designed. This results in safety hazards for users, particularly during summer nights when the park is overcrowded. The same problem also exists in phase 2 of the park: boundaries between the paths are not applied in most parts. The lack of boundaries frequently causes interferences or crashes, especially in the cases of children, elderly people and people with walking disabilities.
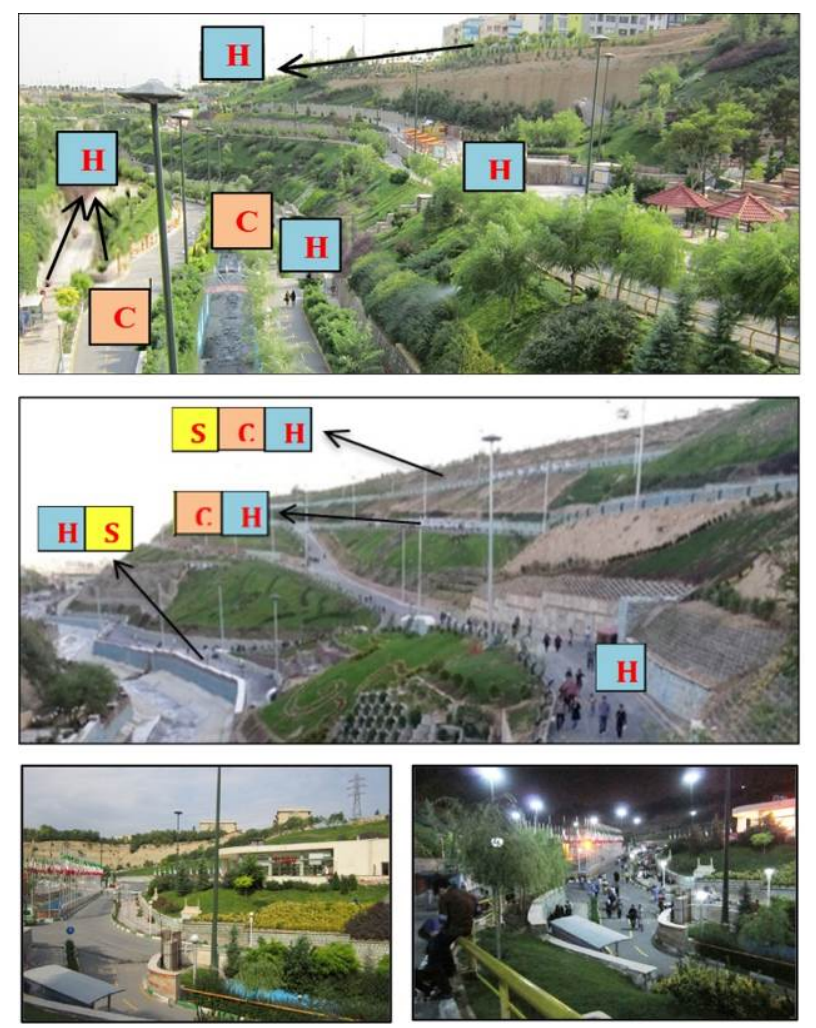

Figure 14. (Top) Nahj-ol-Balagheh Park (phase 1) (2012): hiking and cycling paths at different height levels (H: hiking, C: cycling); (middle) Nahj-ol-Balagheh Park (phase 2) (2013): hiking, cycling and skating paths at different height levels (H: hiking, C: cycling, S: skating); (bottom) Nahj-ol-Balagheh Park (phase 1) (2012): entrance (Source: Author, 2012-2013)

\subsection{Javanmardan-e-Iran Park}

Similar to the case of Nahj-ol-Balagheh Park, the concept of breaking down the height difference by defining horizontal layers is applied in Javanmardan-e-Iran Park in the Kan river-valley. In this park, three types of path including one $24 \mathrm{~km}$ path for hiking, one $8 \mathrm{~km}$ path for horse-drawn phaeton and one $8.7 \mathrm{~km}$ path for cycling - have been designed alongside the river at different height levels [31]. Similar to Nahj-ol-Balagheh Park, the lack of necessary boundaries between these paths usually causes undesirable interferences and collisions between users. In this park, yellow and blue lines painted on the ground shape the scope of each path.
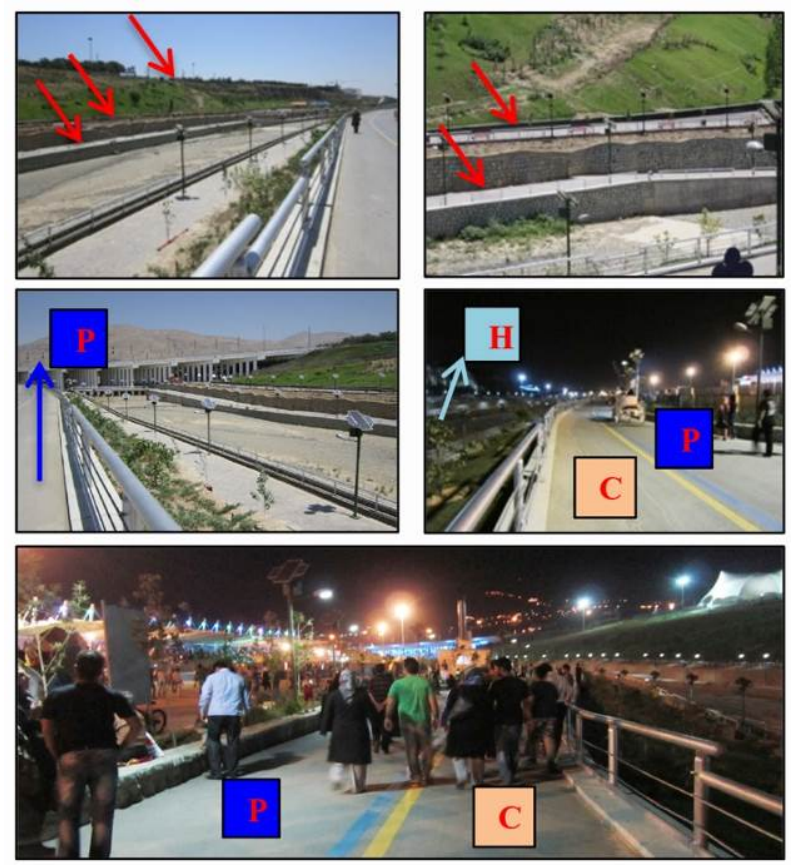

Figure 15. (Top) Javanmardan-e-Iran Park: horizontal layers in the height; (middle) hiking, cycling and phaeton paths alongside the river at different height levels (H: hiking, C: cycling, P: phaeton); (bottom) interferences in activities (P: phaeton, C: cycling) (Source: Author, 2012)

Direct appraisal of this park showed that most hikers refuse to use hiking paths at the lowest level (beside the river). This might be due to the fact that many hikers experience the feeling of being located in too high depths when walking beside the stone walls of the lowest level. Therefore, a major challenge in breaking down the height by means of defining the horizontal layers is to determine the appropriate number of layers alongside the river.

The direct observation at the linear park of Nahj-olBalgheh revealed an interesting finding. On one hand, the horizontal layers alongside the river have created suitable paths for mobile sports such as hiking and cycling and have made it possible for users to experience various perspectives. On the other hand, this linear design has made the park unsuitable for people who wish to spend more time on activities such as a day of picnicking or full-day cultural 
events such as Sizdah-be-Dar. Currently, Norouz is identified as the Iranian New Year, at the spring equinox. Norouz, the biggest national celebration of the start of spring, has special customs and traditions that are dependent on or related to nature. Currently, Norouz is a 13-day celebration in Iran, and the last day - the 13th day of Norouz - is called Sizdah-be-Dar. In the Persian language, Sizdah means 13, be means 'to', and dar means 'door'; therefore Sizdah-be-Dar means 'staying outside the door'. In other words, it refers to staying outdoors, whether within the city or in the countryside.
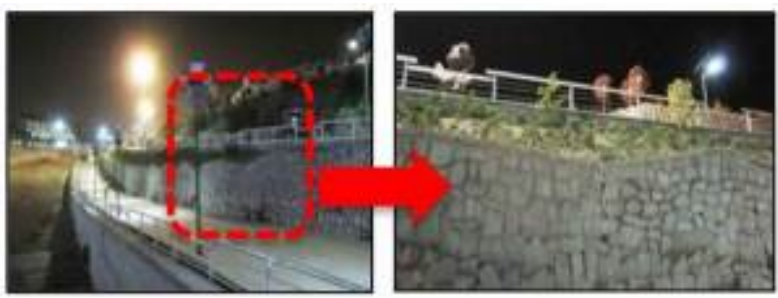

Figure 16. Javanmardan-e-Iran Park (2012): stone walls of the lowest level (Source: Author, 2012)

As explained by Madanipour [32] in 2003, individuals tend to maintain a larger personal space when rooms are narrower in shape. People also require more personal space when they are seated, when they are indoors and when they are in crowded areas [32, 33]. Hence, on crowded days such as Sizdah-be-Dar - when families pass the whole day in natural surroundings - one needs a relatively larger personal space. The direct observation showed that narrowshaped linear parks are not a favourite choice when it comes to spending time outdoors at specific times such as Sizdah-be-Dar. People prefer open and flat, green areas at such times. Open and flat natural spaces, such as the big parks in Tehran and green areas in the countryside, are superior options for spending several hours in the open air.

\section{Physical Perceptions of the River}

Studying perceptions of the river requires full investigation of three key issues. These include the river continuity and flow of water, river walls and fencing, and the water quality of the river. These three factors are studied in detail in each of the three linear parks below.

\subsection{River Continuity and Flow of Water}

Direct appraisal at the three linear parks revealed the possibility of the pleasant experience of hearing the sound of the river flowing while carrying out different activities. In other words, the users of the parks can hear the sound of the flowing water of the river while they are involved in hiking, cycling, eating together with family members in the pergolas, drinking a beverage in a café, sitting on a bench and talking with a friend, or simply reading or studying. This shows that users continuously hear a pleasant sound during their activities as the river flows throughout the whole length of the park. At no point is the river partly covered or constructed as covered canals. In all three linear parks of Park-e-Saheli, Nahj-ol-Balagheh and Javanmardan-e-Iran, the concept of river continuity throughout each park is well respected in the design.

In Javanmardan-e-Iran Park, at the moment, the water does not flow in the main river's path. Rather, it is stored in a reservoir located in the northernmost part of the park below the Hemmat highway. As explained by the mayor of district 22 of Tehran, the water will soon return to the main path once phase 2 of the park is completed [31].
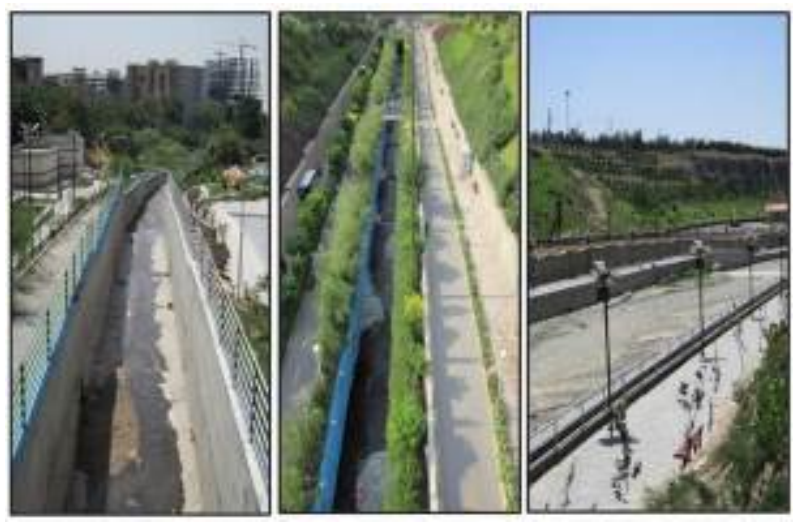

Figure 17. River continuity throughout the park: (left) Park-e-Saheli (2013); (middle) Nahj-ol-Balagheh Park (2012); (right) Javanmardan-eIran Park (2012) (Source: Author, 2012-2013)

\subsection{River Walls and Fencing}

As explained by Mann [34] in 1973, 'the most intensively used and most often abused resource on the earth ... [is] the river in the urban region' [p.13]. There are various approaches to the interpretation and classification of waterside uses in urban areas. Decision makers, however, have always considered one important factor in analysing and planning for watersides through these various approaches: the degree of integration or the degree of water dependency [34-37].

Analysing the degree of integration is necessary when making decisions about possible functions in the neighbourhoods of the river. One also needs to study the possible activities within the determined function(s) of each river neighbourhood. This will then form the perceptions of the river. The following diagram (Figure 18) further clarifies this point. 


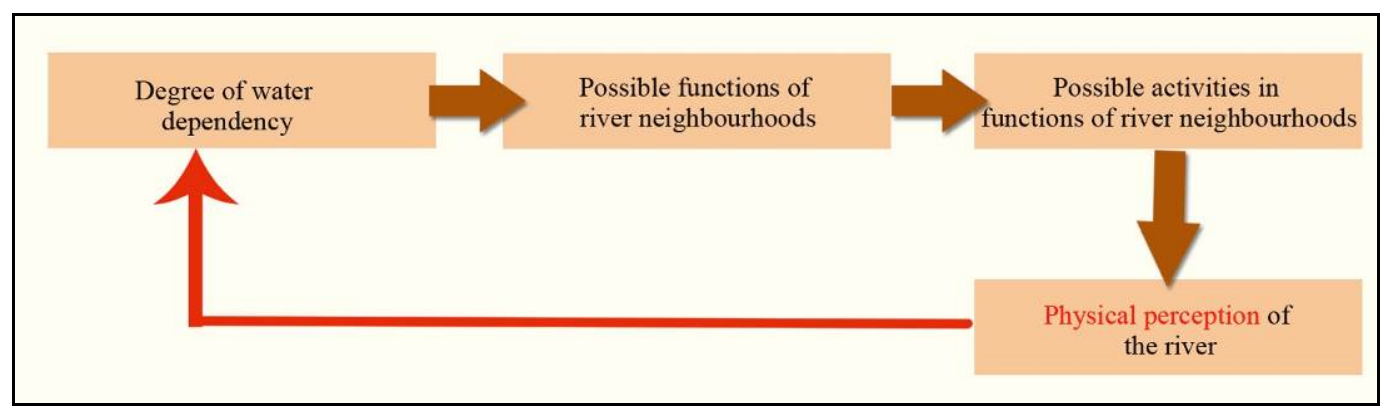

Figure 18. Diagram of the role of water dependency in perceptions of the river (Source: Author, 2013)

As the above diagram shows, the degree of water dependency is an essential element in forming perceptions of the river. To study the degree of water dependency, one should first investigate how the scope of the river is shaped. River walls and fencing represent two main factors in forming the scope of the river, and these are discussed further in this section.

\subsubsection{Park-e-Saheli}

In the Park-e-Saheli project, concrete walls determine the path of the river flow. These walls have rough cement on the interior surface and are painted blue on the exterior façade. In this semi-mountainous park, such concrete walls have replaced mountainous rocks and stones on the sides of the river. Furthermore, because of the height of these walls, the river seems to be flowing at depth. Hence, users have very little or no visual interaction with the river at some parts of the park. In addition, green metal rails of fencing are placed above these walls for safety purposes. The fencing is, indeed, very high and, at some points, it exceeds average human height.

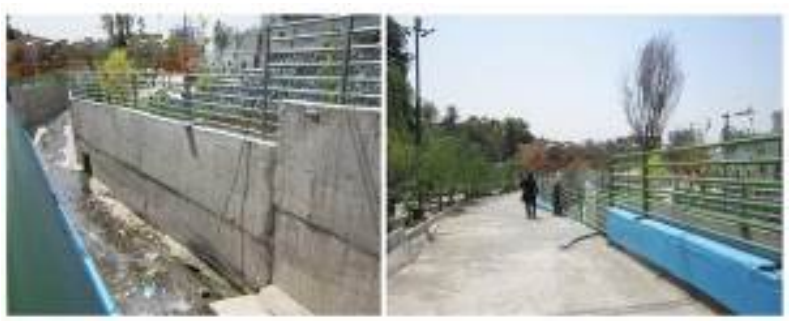

Figure 19. Park-e-Saheli project (2013): (left) exterior and interior surfaces of the river walls; (right) fencing above the river walls (Source: Author, 2013)

\subsubsection{Nahj-ol-Balagheh Park}

Similar to the Park-e-Saheli project, in phase 1 of Nahjol-Balagheh Park, concrete walls with blue painted surfaces represent the sidewalls of the river. In comparison to the walls of Park-e-Saheli, these walls are lower since the river is located at a lower depth. These walls reach the first horizontal layer of the park.

Beside these walls, green bushes and shrubs can be seen planted alongside the river. In addition, yellow metal fencing is used here for safety purposes. In this park, plants and green elements that serve as river boundaries are fully compatible with the existing natural structure of the rivervalley. However, the extensiveness of these bushes and their continuity throughout the whole length of the river make it very difficult for users to have any visual interaction with the water while walking or cycling at the lowest level. In fact, the river becomes partially visible only at some further distances and higher horizontal layers of the park.
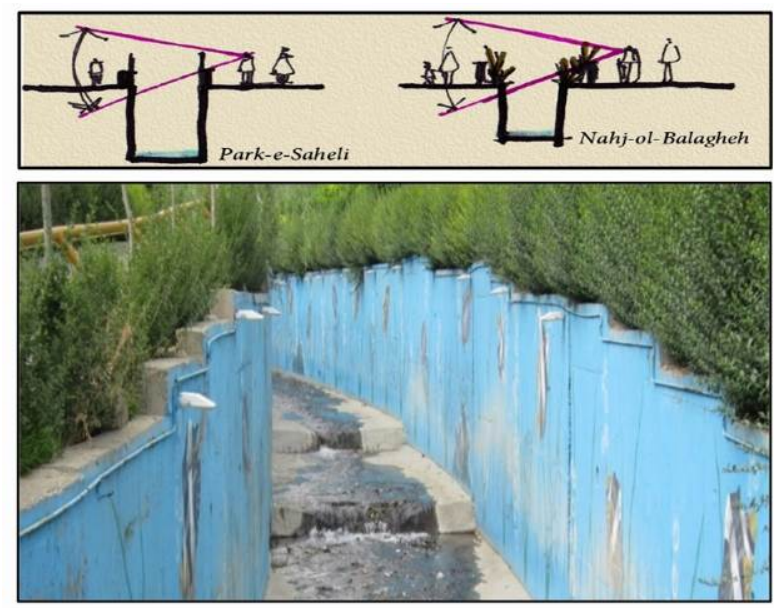

Figure 20. (Top) Comparison of river walls and fencing at Park-eSaheli and Nahj-ol-Balagheh; (bottom) Nahj-ol-Balagheh park (phase 1) (2012): river walls and their interior surfaces (Source: Author, 2012)
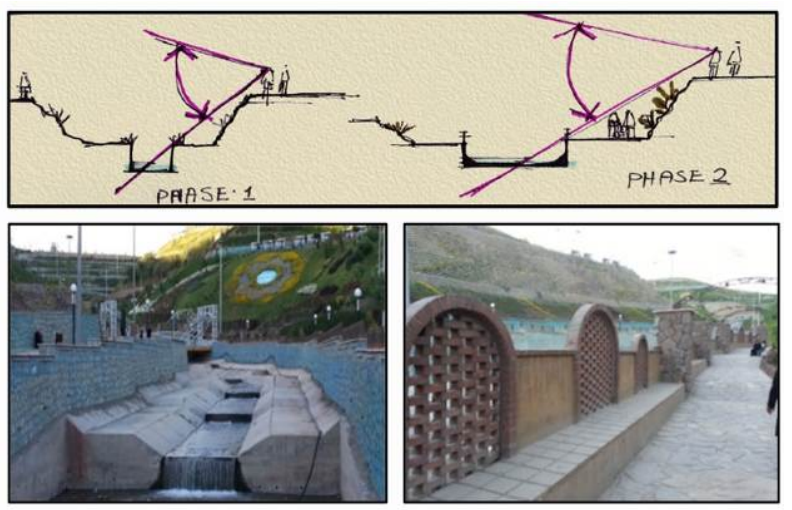

Figure 21. (Top) Nahj-ol-Balagheh park: river width at phases 1 and 2 of the park; (bottom left) Nahj-ol-Balagheh park (phase 2) (2013): river width and river walls; (bottom right) reticulated walls with traditional arches (Source: Author, 2013) 
The river is, by design, wider in phase 2 than in phase 1 of this project. This brings the possibility of more visual interaction with the river at different horizontal levels. Furthermore, in phase 2 of Nahj-ol-Balagheh Park, bluestone patterns are applied to both the interior and exterior surfaces of the river walls. At certain parts of the river, fencing is replaced by continuous walls with traditional arches. Direct appraisal shows that the traditional design of these arches is a very interesting element. However, the choice of materials and the blocked views of the river caused by the continuous walls has negatively affected the views toward the water, particularly for users at the lowest levels.

\subsubsection{Javanmardan-e-Iran Park}

Similar to phase 2 of Nahj-ol-Balagheh Park, at Javanmardan-e-Iran Park, the river is expected to be wide and flow at a low depth. A blue-stone pattern has also been used here on the interior and exterior surfaces of the river walls. However, the river walls are lower and the fencing above them is more moderate compared to that of Nahj-olBalagheh Park.

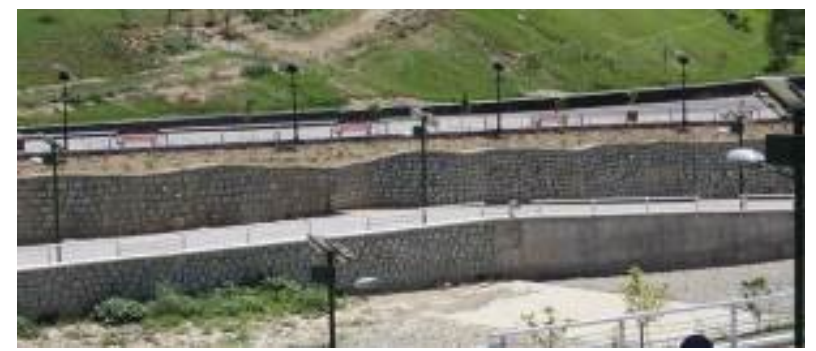

Figure 22. Javanmardan-e-Iran Park (2012): river walls and fencing (Source: Author, 2012)

Several elements, including the low depth of the water, the low height of the river walls and the moderate fencing, make it possible for users to have visual interaction with the river at all horizontal layers and even at the layer that is closest to the river. Since the water is currently (and until the completion of phase 2) maintained in a reservoir located at the northernmost point of the park, it is not possible to study this interaction further at the moment.
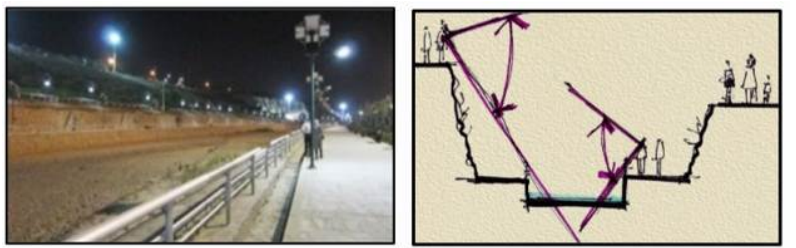

Figure 23. Javanmardan-e-Iran park (2012): (left) river width and fencing; (right) perspectives of the river from different layers of the park (Source: Author, 2012)

\subsection{Water Quality of the River}

According to statistics from the Air Quality Control
Organization of Tehran in 2015, the level of air pollution in Tehran has increased significantly in the past few years[38]. Due to the continuous air pollution in Tehran, Tehranians tend to consider natural places such as linear parks as idea locations from which to take fresh air. Although the design and the function of the parks in urban contexts have changed significantly through the ages, citizens have always considered parks as offering protection from urban pollution and its consequences [11,38,39].

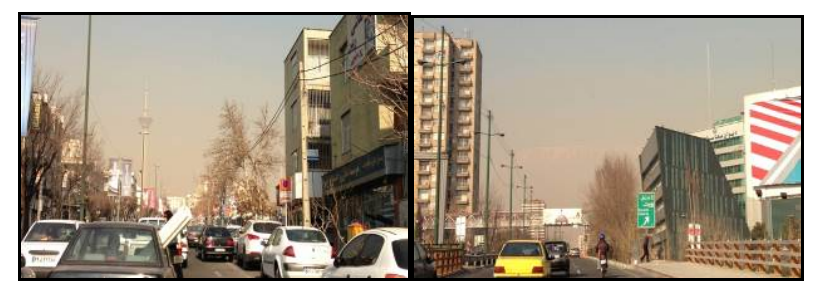

Figure 24. Visible air pollution in Tehran (2013) (Source: Author, 2013)

As Short [40] noted in 2006, the use of automobiles in cities is mainly responsible for air pollution and congestion. Research shows that people who live in crowded cities for over fifteen years could lose $50 \%$ or more of their hearing capabilities. In crowded and polluted cities, the level of stress is usually high and the quality of urban life can be poor [40]. In the crowded city of Tehran, which has a provincial population of around 13 million, as a result of the high level of pollution, residents recognise natural places such as parks as havens where they can rid themselves of their daily stresses for at least a few hours[7,8].

\subsubsection{Park-e-Saheli, Nahj-ol-Balagheh and Javanmardan- e-Iran Parks}

In these three linear parks, river pollution has caused unpleasant smells and additional air pollution, especially at the lowest horizontal layer. To make sure the river has pure and high-quality water, it is necessary to think of a comprehensive process of design and planning for the whole length of the river in the urban region. A continuous and pure flow of river water in the urban context could create a linear landscape for citizens who look for a way to escape from the daily urban chaos. This continuity and purity can only happen if the whole length of the river and its neighbourhoods are studied in detail.

One reason for the water pollution in the linear parks is the implementation of projects at certain parts of the river. Indeed, the river usually passes through polluted areas and covered canals in the urban regions, and thus sometimes carries different types of waste. The waste materials accumulate along the river path from the northernmost to the southernmost points. This issue causes further problems in the southern parts of Tehran in particular. Figures 25 and 26 show the prevalence of this problem in various parts of Tehran. 

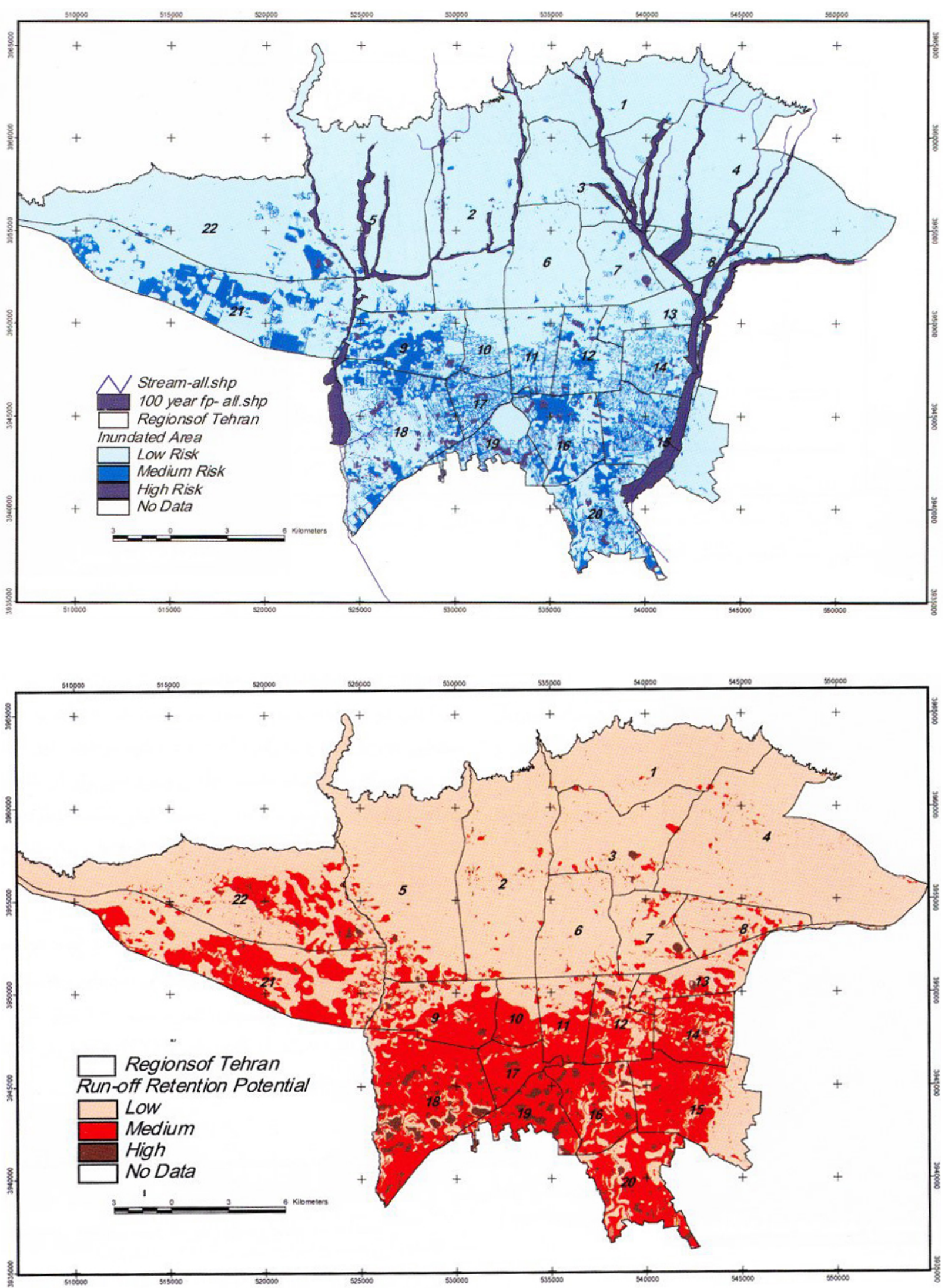

Figure 25. (Top) Regions of Tehran in terms of inundated areas (Source: Reference [41]); (bottom) regions of Tehran in terms of run-off retention potential (Source: Reference [41]) 
Although garbage accumulation occurs along the whole length of the river, it only becomes visible at uncovered parts such as certain locations in the linear parks [11,42]. Accumulation of waste from the northernmost to the southernmost parts of the river in the urban context is the major reason for river pollution in all three linear parks. The following images in Figure 26 further clarify this point.
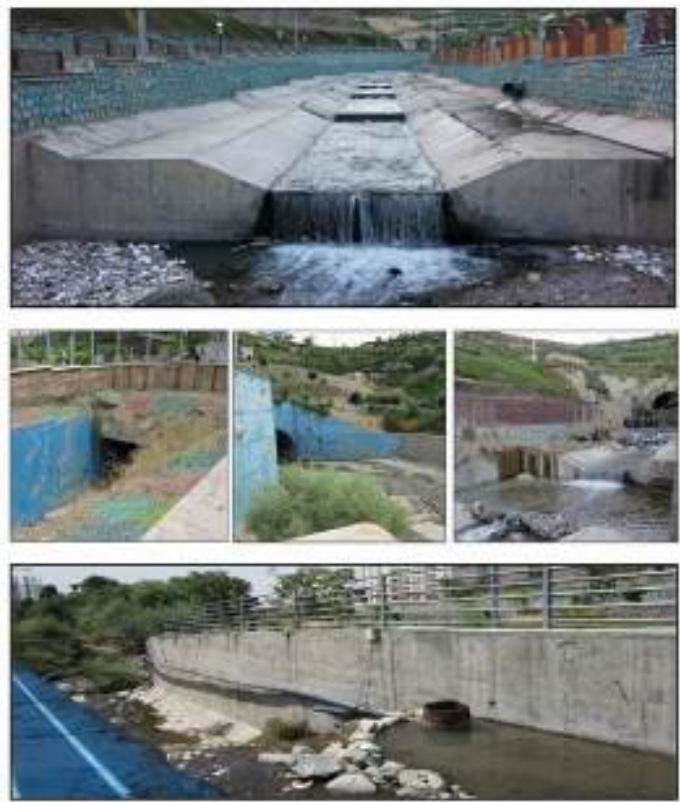

Figure 26. (Top) Nahj-ol-Balagheh Park (phase 2) (2013): visible river pollution; (middle) Nahj-ol-Balagheh Park (2012): covered canals at the entrance and exit points of the river in the park; (bottom) Park-e-Saheli project (2013): river pollution (Source: Author, 2012-2013)

In addition to the abovementioned reason for river pollution in all three parks, there are two other factors in the Park-e-Saheli project that also increase the level of pollution. As explained previously, there are two hospitals, Masih Daneshvari (hospital and National Research
Institute of Tuberculosis and Lung Diseases) and Artesh (army), in the neighbourhood of this park. The medical waste from these hospitals, especially from Masih Daneshvari hospital, enters the river and causes additional amounts of pollution and unpleasant smells along the walking paths beside the river $[43,44]$. Furthermore, one of Tehran's major garbage transfer stops is located to the south of this park, and this causes further unpleasant smells throughout the park, and in the southernmost areas in particular. The locations of the two hospitals and the garbage transfer stop are shown in the following figure (Figure 27).

\section{Physical Perceptions of the Height Difference}

The practice of using height difference in design through the definition of horizontal layers has been explained in previous sections. The process of defining the horizontal layers changes the perception of the height difference for those located in different parts of the area. Standing at the lowest horizontal layer of a linear park feels like standing in a valley. In contrast, standing at the highest layer feels like being on top of a mountain. The height difference in the discussed linear parks creates a perception of being located in a deep valley. There are two reasons for this. First, the highest points of these parks and the main streets of the neighbourhood are at the same height level. As a result, pedestrians in the main streets notice that the park is located at a certain depth. Second, the height difference between the existing horizontal layers is high compared to the width of those layers. This creates a feeling of enclosure and high depth $[17,45]$. Furthermore, in some parts of the parks, the height difference is used in vertical or semivertical walls covered by stones and grass. The following images in Figure 28 further clarify this point.

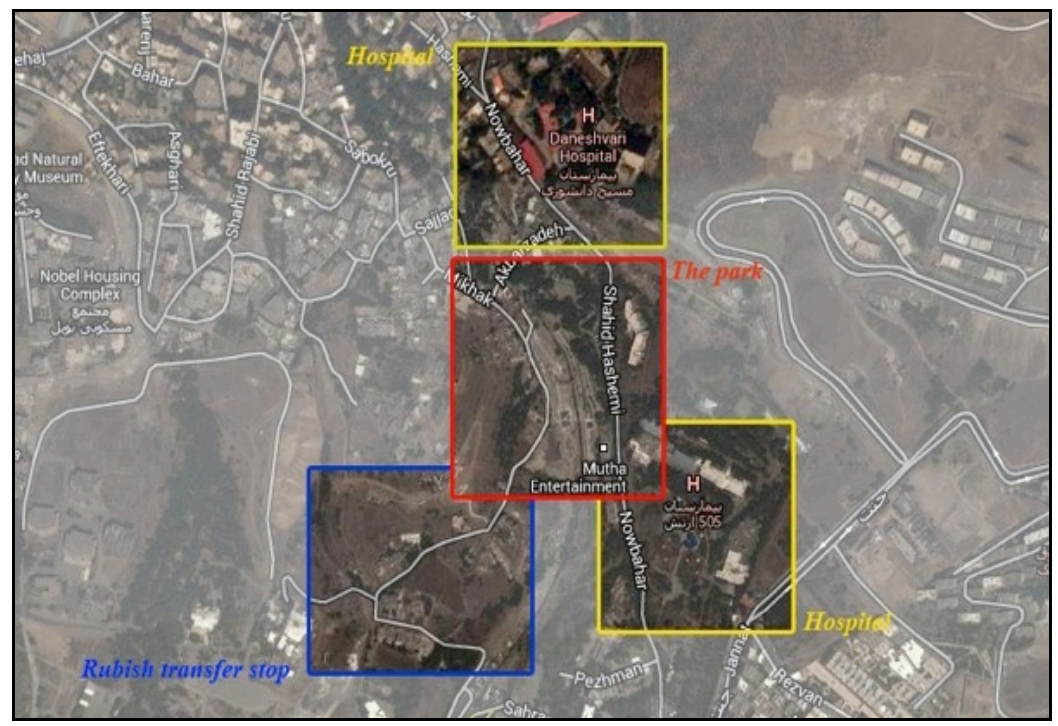

Figure 27. Park-e-Saheli project: functions incompatible with the river- valley in the neighbourhood (Source of the base map: Reference [30]) 

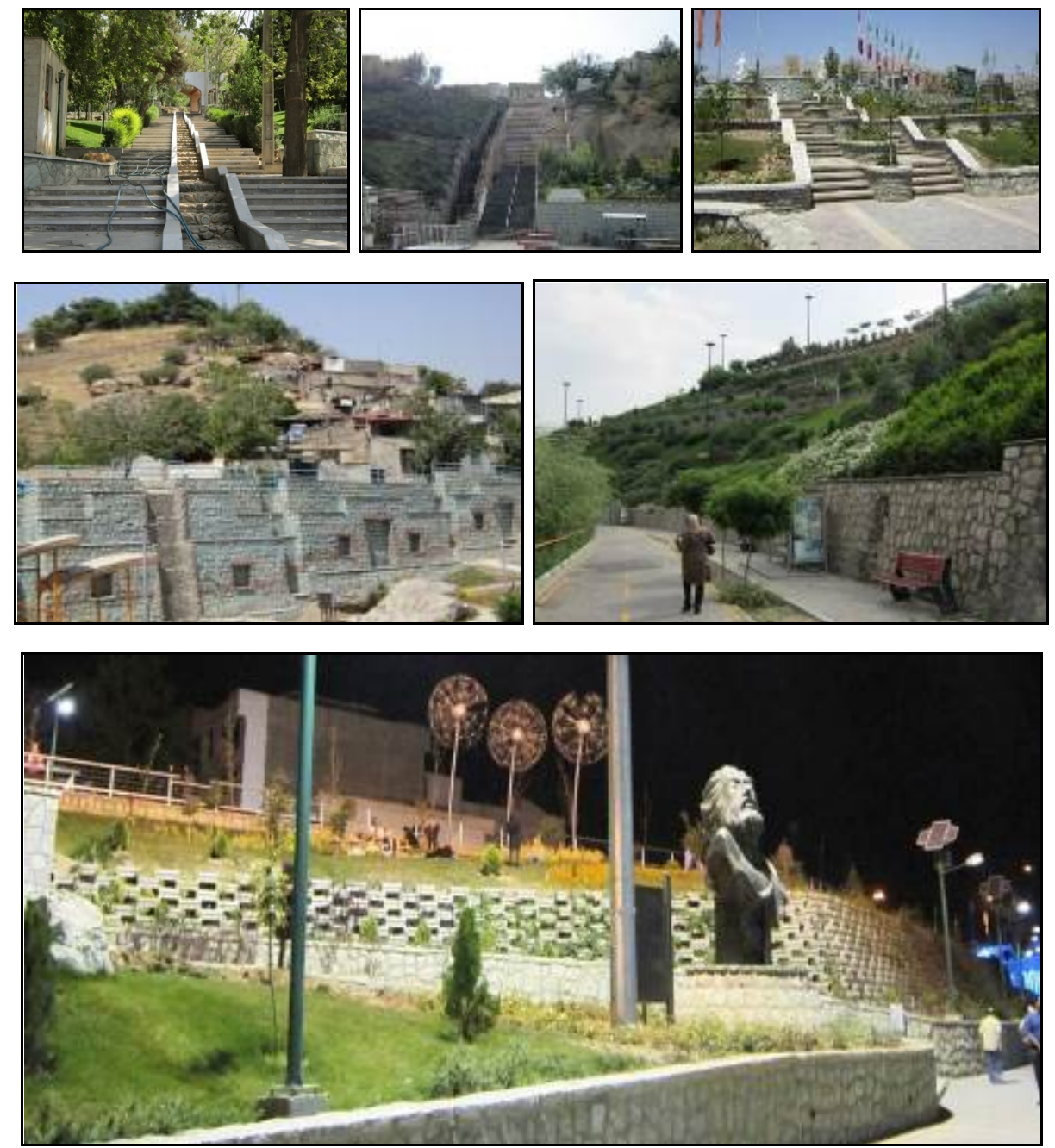

Figure 28. Stairs at the main entrance from the main street level: (top left) Park-e-Saheli (2013); (top middle) Nahj-ol-Balagheh Park (2012); (top right) Javanmardan-e-Iran Park (2012); (middle) vertical and semi- vertical walls covered by stones and grasses - view from the lowest horizontal levels - (middle left) Park-e-Saheli (2013); (middle right) Nahj- ol-Balagheh Park (2012); (bottom) Javanmardan-e-Iran Park (2012) (Source: Author, 2012-2013

\section{Bridges over the River}

Considering the existing problems within the linear parks through direct observation, one issue is the unsuitable connection between different parts, specifically between the two sections of the valleys in the linear parks. In other words, the number of connecting bridges, as well as the number of stairs to those bridges, have created connection and access difficulties. Hence, bridges over the rivers to connect the two sections of the valleys are further studied. The number, location and designs of these bridges affect users' level of accessibility and thus their experiences of different areas of the river-valleys in the parks. As a result, it is required to investigate the role of bridges in shaping the interactions between users and the existing natural structures of the river-valleys in the three linear parks.

\subsection{Park-e-Saheli}

In the Park-e-Saheli project, there is only one connecting bridge over the river. This bridge is not particularly high. Hence, it does not have too many stairs and this facilitates easy access to both sides of the river-valley. However, there are no access ramps for users with disabilities or movement difficulties [17]. The design of this bridge is shown in Figure 29.
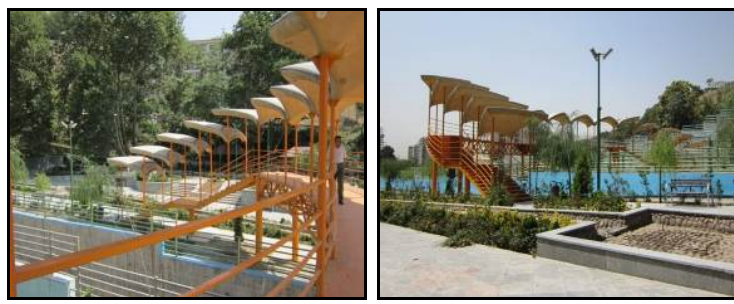

Figure 29. Park-e-Saheli project (2013): the bridge over the river (Source: Author, 2013)

\subsection{Nahj-ol-Balagheh Park}

In phase 1 of Nahj-ol-Balagheh Park, one high bridge 
connects the two highest horizontal layers of the park. There are a further four small bridges over the river that connect the two lowest horizontal levels of the valley. Through in direct observation, considering the number of users on crowded days and nights revealed that just one bridge throughout the whole length of the river is not sufficient. The excessive number of stairs to this bridge makes accessibility very difficult for the majority of users. Indeed, the majority of users prefer to stay in one section rather than experiencing both sides of the park due to the difficulty of accessing different sections.
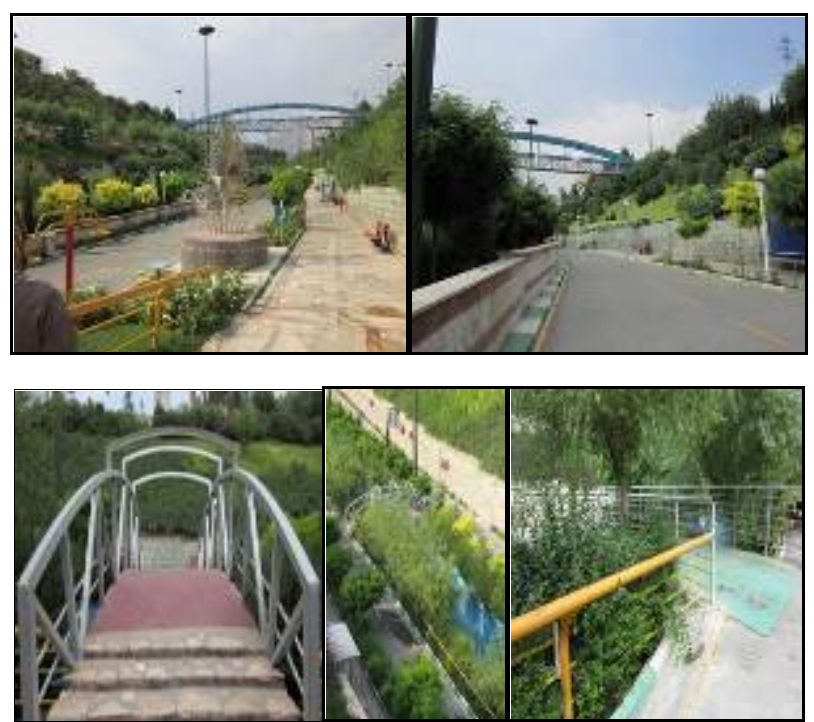

Figure 30. (Top) Nahj-ol-Balagheh Park (phase 1) (2012): the high bridge; (bottom) Nahj-ol-Balagheh Park (phase 1) (2012): small bridges (Source: Author, 2012)

In phase 2 of Nahj-ol-Balagheh Park, there are two connecting bridges at the lowest level. There are no high bridges connecting the two sections of the valley. This makes it very difficult for users to experience both sections of the river-valley.
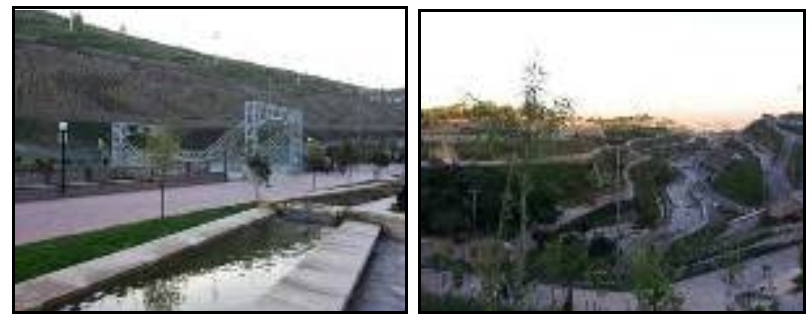

Figure 31. Nahj-ol-Balagheh Park (phase 2) (2013): the bridge over the river: (left) the bridge at the lowest level; (right) lack of in-height connection (Source: Author, 2013)

\subsection{Javanmardan-e-Iran Park}

In Javanmardan-e-Iran Park, three arc-shaped bridges have been designed over the river. These bridges connect the mid-height horizontal layers of the two sections of the river-valley. The arc-shaped design facilitates access to both sections of the river-valley. Identifying the number of bridges here is only possible when the river is flowing. Users who stand on these bridges have a panoramic view of the park as well as the river. Hence, more people might be interested in standing on these bridges for a longer period of time once the water is released from the reservoir. This suggests that more bridges throughout the river might be required in the future. In both traditional and modern designs in Iran, bridges serve as pause points as well as transit paths [19, 46-52].

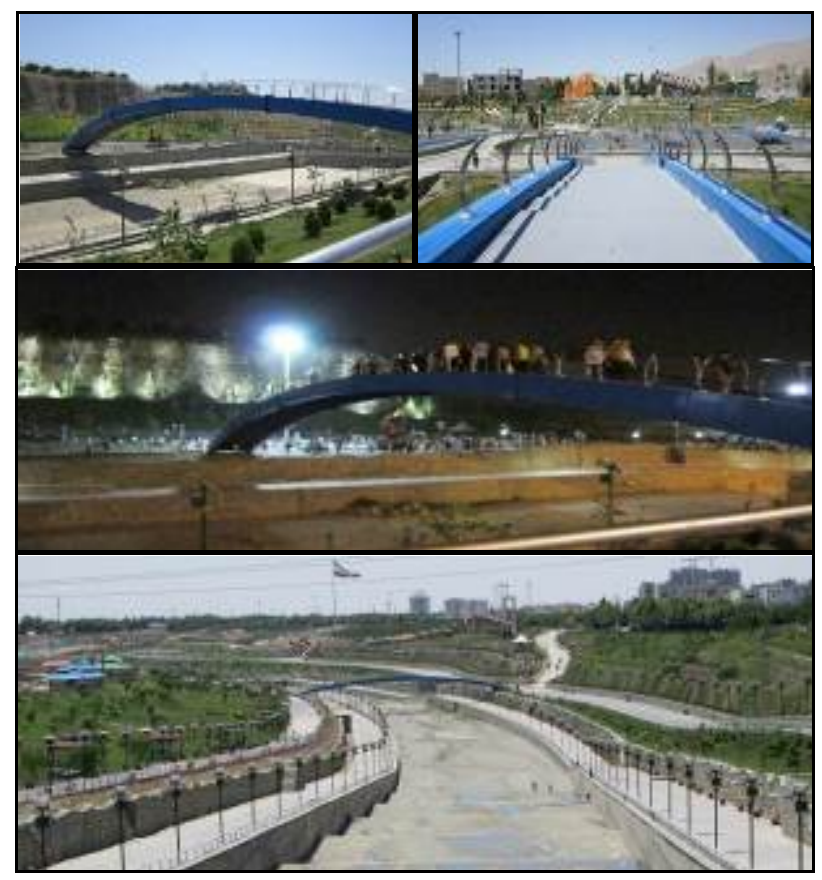

Figure 32. (Top) Javanmardan-e-Iran Park (2012): arc-shaped bridge over the river; (middle) Javanmardan-e-Iran Park (2012) - the number of people using the bridge; (bottom) Javanmardan-e-Iran Park (2012) - the perspective towards the park from a bridge (Source: Author, 2012)

\section{Facilities}

In order to study the facilities of these linear parks, it is necessary to investigate the users' opinions about them. In other words, it is necessary to understand users' willingness to use the existing facilities in the area such as sports facilities, restaurants, cafés, 5D cinema and playgrounds. This paper classifies the present facilities into three groups: the satisfactory facilities that people are interested in using; facilities that do not have a direct impact on users' experiences; and facilities that people would like to see changed, removed or substituted with other functions. To study the needs and the problems of the citizens with regard to the river-valleys in the linear parks, it is necessary to investigate how the existing facilities affect users' experiences of the river-valleys.

\subsection{Park-e-Saheli project, Nahj-ol-Balagheh Park and Javanmardan-e-Iran Park}

The existing and diverse sports facilities, their locations 
and accessibility, and the vast amount of space allocated to sports are the key reasons for the popularity of these facilities. In order to study how these factors affect the interaction between users and the existing natural structures of the river-valley, a detailed study of the existing sports facilities is necessary. In the case of the Park-e-Saheli project, playgrounds and sports facilities are yet to be completed. Therefore, further analysis is not currently possible.

\subsection{Nahj-ol-Balagheh Park}

In Nahj-ol-Balagheh Park, small-scale sports facilities exist at certain points along the cycling and hiking paths. These facilities - including ping-pong tables, chess tables, etc. - are set along the whole length of the paths at regular intervals.

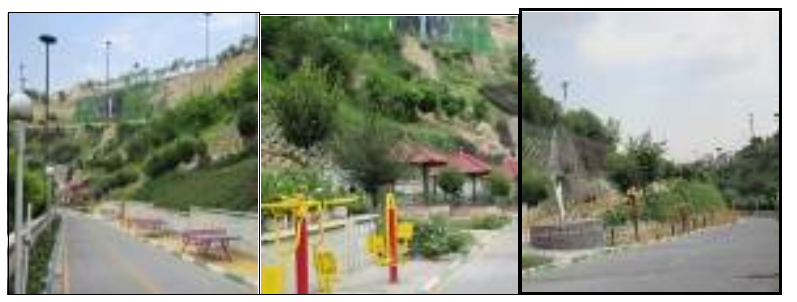

Figure 33. Nahj-ol-Balagheh Park (phase 1) (2012): small-scale sports facilities alongside the hiking paths (Source: Author, 2012)
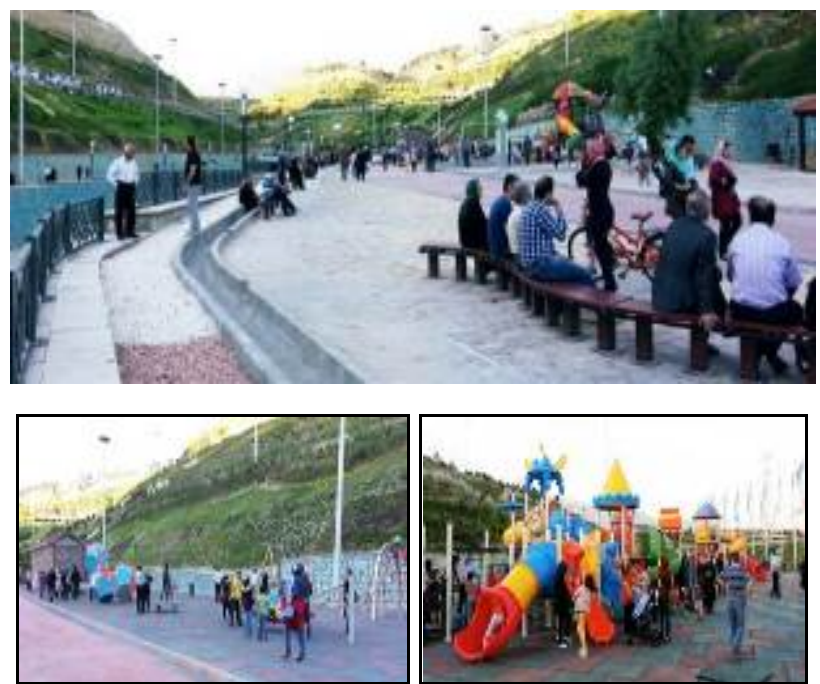

Figure 34. (Top) Nahj-ol-Balagheh Park (phase 2) (2013): children's playground at the lowest level and families with children; (bottom) Nahj- ol-Balagheh Park (phase 2) (2013): close view of children's playgrounds; (bottom left) the playground at the lowest level; (bottom right) the playground at the mid-height level (Source: Author, 2013)

Direct observation revealed that the small-scale facilities are used mainly by neighborhood residents for daily sports. These facilities not only help users to perform daily exercises but also lead to greater interaction with neighbors. In addition to the small-scale sports facilities, there are also two playgrounds for children under 14 in phase 2 of Nahj-ol-Balagheh Park. The first playground is located on the lowest level of the river-valley. The second playground is located on the mid-height horizontal level of the park. Direct appraisal showed that users in general like to experience different perspectives of the park by spending time at different horizontal layers. However, families with young children tend to be limited to levels that include playgrounds. Indeed, parents of young children are mostly restrained by the limited number of playgrounds and the limited space allocated to these.

\subsection{Javanmardan-e-Iran Park}

According to the Municipality of district 22[31] in 2012, there are two types of playground in Javanmardan-e-Iran Park: 1) playgrounds for children under 14 (4,160 square metres), and 2) playgrounds for adults (9,355 square metres). The large space (around 9,000 square metres) allocated, the variety of equipment offered, and the possibility of easy access have made the playgrounds highly attractive for users. This, however, might prevent users from visiting other parts of the park such as the different horizontal layers that provide various perspectives of the river-valley. In other words, users might choose to spend their time exclusively in overcrowded playgrounds so that they can play with the modern and high-tech sports equipment.
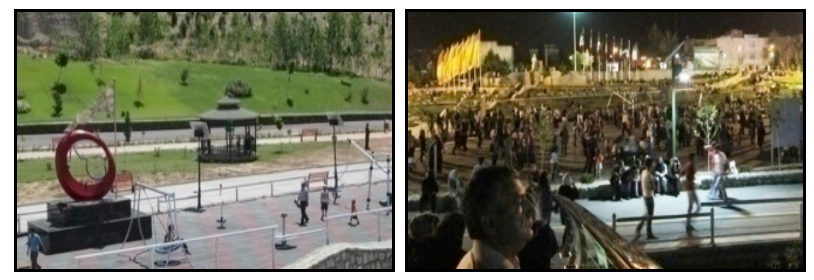

Figure 35. Javanmardan-e-Iran Park (2012): children's playground and adults' playground (Source: Author, 2012)

In this park, there is also a skating rink (4,600 square metres), which is used by both professionals and beginners. It also serves as a temporary performance stage at specific times such as the nights of the holy month of Ramadan. In the past ten years, the Municipality of Tehran has organised many entertainment programmes in the major parks during Ramadan nights. These programmes include interactive games, singing performances by famous artists, and live interviews with well-known personalities. On the same site, users can also visit exhibitions of handicrafts from different regions of Iran. These programmes and exhibitions are the main reasons why many Tehranians visit these parks. However, visiting the park usually leads also to a conscious or subconscious interaction with the natural structures.

Generally, the skating race games and the performances encourage users to stay in a limited area rather than to explore the existing natural structures of the park. At present, the skating area and the high-tech playgrounds form the two most popular attractions in the park and encourage a significant number of people to visit. However, 
this might restrict users to a limited area rather than providing the opportunity of excursion through the existing natural structures of the park. In other words, using these high-tech playgrounds in the park might be the starting point of familiarization for a considerable number of Tehranians with the existing river-valleys of Tehran.

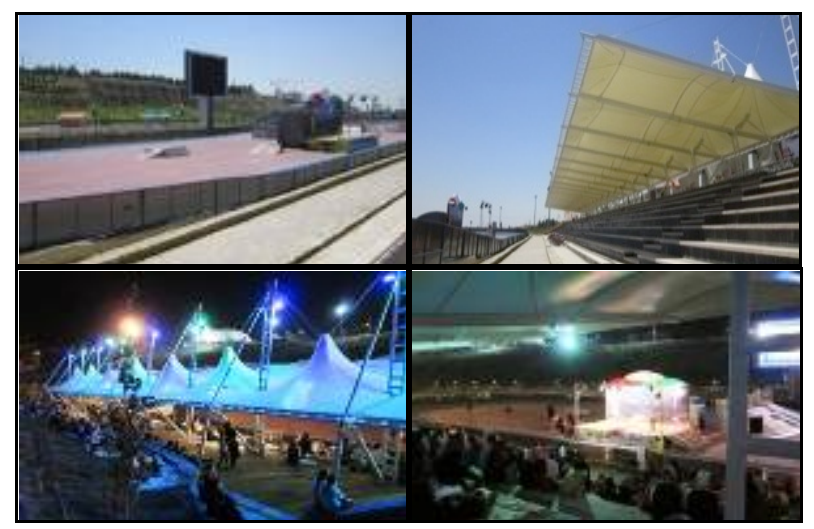

Figure 36. (Top) Javanmardan-e-Iran Park: skating playground; (bottom) Javanmardan-e-Iran Park (2012)-temporary stage at the skating playground during Ramadan (Source: Author, 2012)

\section{Lighting}

As explained by Madanipour [32] in 2003, promotion of public spaces is a vehicle to confront fragmentation in cities. Promotion of the sense of togetherness is realised in various definitions of public space. According to Walzer[53] in 1986, public space is 'space we share with strangers ... space for peaceful coexistence and impersonal encounter' $[53$, p.470]. Since sharing with strangers is a common behaviour displayed in public spaces, safety is a key factor for visitors. Direct observation in the linear parks showed that the lighting in the parks could play a fundamental role in creating feelings of safety for users. In other words, feelings of safety, lighting and the use of an area at night are three interrelated factors that strongly affect users' experiences of the area. Hence, the use of lighting in the three parks is studied in detail in this section.

\subsection{Park-e-Saheli}

In the Park-e-Saheli project, lights are set out along the river at regular intervals on both sides of the hiking paths and the stairs. This provides sufficient lighting within the park, especially on summer nights. Park-e-Saheli offers only one type of activity, that of hiking, along the river. Hence, no additional lighting is required at intersections. In the other two linear parks, however, different types of activity take place, including hiking, cycling, skating and horse-drawn phaeton. Therefore, additional lights at intersections are required to ensure the safety of users. Additional lighting leads to better visibility at the intersections and helps to prevent accidents.

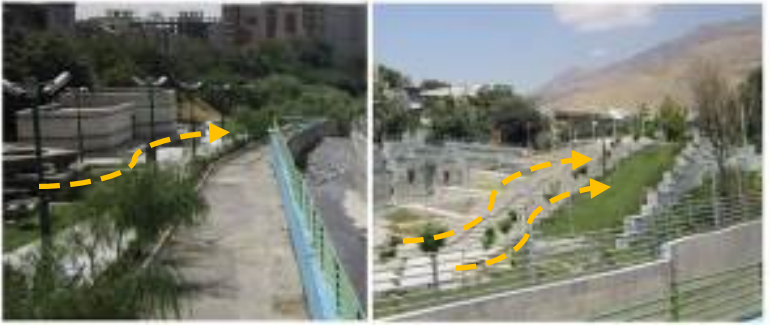

Figure 37. Park-e-Saheli project (2013): lighting alongside the hiking paths and stairs (Source: Author, 2013)

\subsection{Nahj-ol-Balagheh Park}

The direct observation in Nahj-ol-Balagheh Park showed that adequate lighting in the park creates feelings of safety for users, especially during summer nights. The high number of visitors during summer nights suggests that people in general find the park safe. The results of the direct appraisal showed that Tehranians stay in the park until 2 am on summer nights.
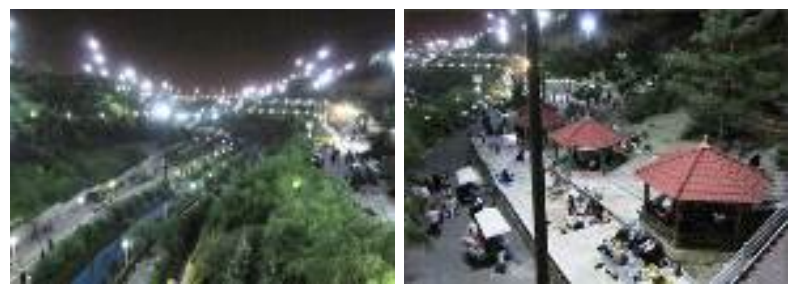

Figure 38. Nahj-ol-Balagheh park (2012): lighting in the park, crowds of people during summer nights (Source: Author, 2012)

\subsection{Javanmardan-e-Iran Park}
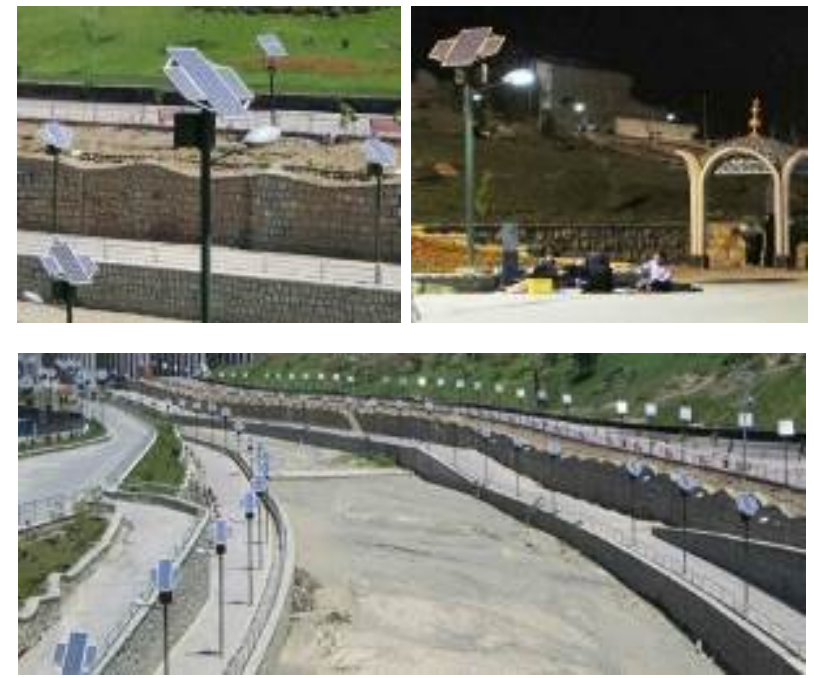

Figure 39. Javanmardan-e-Iran Park (2012): lighting via solar panels; Javanmardan-e-Iran Park (2012) (Source: Author, 2012)

Similar to the case of Nahj-ol-Balagheh Park, in Javanmardan-e-Iran Park, adequate lighting persuades Tehranians to spend a few hours in the park during summer nights. In this park, several rows of solar panels have been installed along the river and the existing paths. Use of these 
panels by the municipality indicates concerns regarding sustainability, and suggests that the municipality is gradually shifting towards sustainability in urban projects.

Images of the lighting in the park can be seen below. This colourful lighting is used at the northernmost point of the park, below Hemmat Bridge.
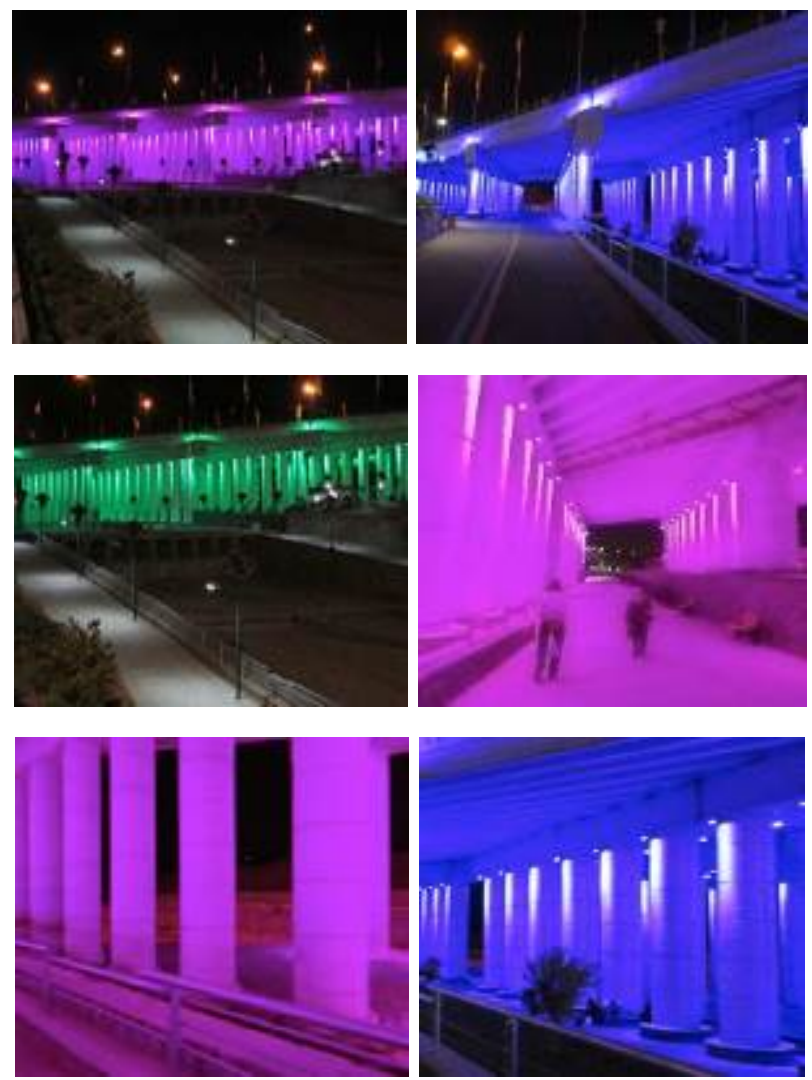

Figure 40. Javanmardan-e-Iran Park (2012): colourful lighting in the area of Hemmat Bridge (Source: Author, 2012)

\section{Accessibility and Parking Spaces}

Accessibility is one of the main challenges in modern cities in terms of the interaction between citizens and natural structures. As such, in studying the human-nature relationship in the three linear parks, it is necessary to investigate how users access the area and how they evaluate the ease of access (e.g. distances, commute time, availability of parking spaces, etc.).

\subsection{Park-e-Saheli, Nahj-ol-Balagheh Park and Javanmardan-e-Iran Park}

Direct appraisal showed that, in general, residents of the neighbourhoods of these three parks are dissatisfied with the excessive number of people and cars in the area. Neighbourhood users experience problems such as heavy traffic, air pollution and sound pollution, specifically during summer nights. A number of local residents even have difficulty finding parking spots for their cars, as non- neighbours usually take all available spaces in the alleys and streets within the area. In contrast, users coming from further afield are mostly satisfied with parking provision, but they also demand more spaces.

In conclusion, while a pre-determined parking area acts as a persuasive factor for users travelling longer distances, it results in chaos and inconvenience in the neighbourhood [17,28]. Figure 41 illustrates the allocated parking spaces for non-neighbours and the mostly- occupied parking spots during summer nights in Nahj-ol- Balagheh Park. This example shows how the parking spaces encourage users to access the area using private vehicles.

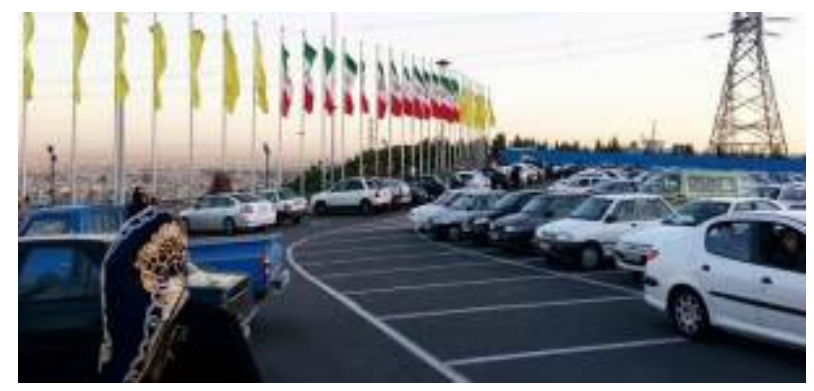

Figure 41. Nahj-ol-Balagheh Park (phase 2) (2013): allocated and occupied parking spaces (Source: Author, 2013)

\section{Conclusions}

When developing effective design and planning strategies, it is necessary to address the existing needs, problems and potentials of both river-valleys and Tehranian users in the current circumstances. With a main focus on direct appraisal, in this research, a literature review and related analysis, as well as direct observation, have been used to study the present and future issues relating to the interaction between Tehranians and the seven river-valleys of Tehran. This paper discusses the findings from the direct observation concerning the implemented projects within the three linear parks within the seven main river-valleys of Tehran. The key issues studied include height differences and horizontal layers, physical perceptions of the river, physical perceptions of the height difference, bridges over the river, facilities, lighting, and accessibility and parking issues. Analysis of the key issues in the parks has enabled clarification of the roles of the parks - as well as potential and problems within the routines and rituals of the Tehranian residents.

To deal with the height differences within the rivervalleys, horizontal layers are defined at different height levels in the linear parks. These layers are used as linear paths for hiking, cycling, skating and phaeton rides along the river. The specific topography of the river-valleys and the existence of the linear paths have resulted in an absence of open and flat, green spaces in the linear parks. This has led to these areas becoming less suitable for certain rituals on specific days such as Sizdah-be-Dar. The reason for the use of the term 'less suitable' rather than 'unsuitable' is the 
preference of some local residents to select these areas for use on specific days. This is mainly because of their close distance and accessibility.

Linear parks are involved in quotidian and specific days of celebration for Tehranians in different ways. Linear parks with linear paths for sports provide opportunities for daily interaction with the existing natural structures of the river-valleys, particularly for neighbourhood residents. As part of the routines of the local residents, these linear parks provide the opportunity for daily exercise, daily visual and aural interaction with the river-valley and green spaces, and daily interaction with other neighbours. Local parks are suitable locations for neighbourhood residents to gather during summer nights and have dinner with family or friends. Hence, linear parks with different horizontal layers and a variety of perspectives towards the river-valley could easily become a part of the routines of neighbourhood residents.

In order to study the needs, problems and potentials of the current interaction between Tehranians and the rivervalleys, one factor that needs to be investigated is how this natural structure, or, more precisely, the concept of the synthesis of the river-valley, is physically perceived in the linear parks. Physical perceptions of the river, and also the physical perceptions of the height differences, have been studied in detail in the three parks. The three factors of the river continuity and flow of water, river walls and fencing, and water quality have been recognised as the main factors that form the physical perception of the river within this natural structure, as explained below. It should be noted that the physical perception of the river strongly affects the experiences of those who visit the linear parks to engage in activities such as dinner with family or sports. It is thus essential to understand and enhance the factors that shape this perception.

River continuity and flow of water facilitate continuous visual and aural interaction with the water. The degree and quality of this interaction depends on the design of the river walls and fencing, as well as the quality of the water. Currently, concrete walls and rigid fences allow users of the three parks to have limited interaction with the river. The severity of this problem, however, varies within the three linear parks. River pollution negatively affects the quality of the interaction with the natural structure of the river-valley and, hence, negatively affects the physical perception of the river. Human-scale littering as well as the lack of a coherent design leading to an accumulation of garbage in a north-south direction have resulted in an unpleasant visual and olfactory experience, particularly in areas close to the river $[11,13]$.

As explained above, a key part of studying the physical perception of the synthesis of the river-valley is an investigation of physical perceptions of the valley, or, more precisely, physical perceptions of the height difference. A valley could potentially be converted into a stair-shaped park that local residents can use on a daily basis $[11,13,24]$.
Hence, it is essential to identify how the height difference is perceived when it comes to the design and planning process for a river-valley. This should, then, clarify the different roles of the parks in the routines and rituals of Tehranians. As such, it is necessary to study the topography of a valley or, more precisely, the height differences within a river-valley when designing future park projects.

Another factor involved in studying the current interaction between users and the river-valleys are the bridges over the river. In the Iranian context, the term 'bridge' implies a connecting path as a pause point as well as a transit point. Today, however, the concept of pausing for visual and audio interaction is rarely considered. This necessitates a revival of the concept of the bridge in the design and planning of parks in the river-valleys.

Facilities form another key factor in forming and affecting human-nature relationships in the three linear parks. These facilities respond well to users' needs within the park and are sometimes the only reason users visit these areas. Hence, these facilities always affect users' interactions with the river-valleys on a conscious or subconscious level. Seeing the river in the background while skating in a professional playground, or hearing the river while eating dinner with family are two examples of such interactions. It is thus helpful to identify facilities that could increase the possibility and the quality of interaction with this natural structure.

In the quotidian activities of Tehranians, linear parks are used during both night and day. In the summer, Tehranians prefer to visit these areas after sunset due to the high temperatures during the day. Hence, lighting is an important factor in shaping experiences in these areas, Sufficient lighting also plays a fundamental role in creating feelings of safety for the majority of users $[11,23]$. Hence, improvements to the lighting are necessary to enhance the role of these areas in the routines of Tehranians.

The final issue in studying the human-nature relationship in the three linear parks is parking spaces. On one hand, pre-determined parking spaces are crucial to accommodate visitors to these areas. On the other hand, such parking zones can encourage many people to use private vehicles to access these areas. To find good balance, several factors should be considered, including the responsive radiuses of the areas, the availability and capacity of public transport, and the allocated parking spaces.

It should be mentioned that this paper opens a platform for discussion on the needs, problems and potentials associated with the human-nature interaction in the implemented projects of the three linear parks built on short specific lengths of three of the seven main river-valleys of Tehran. To this end, seven key categories -mainly related to physical aspects and environmental sustainability - have been studied in detail. Further research could examine the relationship between environmental and other aspects of sustainability such as social and cultural. In a comprehensive sense, all aspects of sustainability should be 
considered in relation to the human-nature relationship in these parks by different scholars in various fields of study. This could result in sustainability being achieved in its full sense within the three linear parks.

This paper has focused mainly on the issues within the three linear parks along the short lengths of three of the seven river-valleys. Further research could examine how these three projects could be related to future practical projects. In other words, the study of these three parks forms a key part of a whole comprehensive design and planning programme for the seven river-valleys of Tehran. This, bottom-up approach, however, necessitates a topdown approach of investigation concerning the natural structures of river-valleys in order to cover the mutual needs, potentials and problems of Tehranians as well as the river-valleys.

\section{REFERENCES}

[1] F. A. Finn. Getting a PhD: An Action Plan to Help Manage Your Research, Your Supervisor and Your Project, London, Routledge, 2005.

[2] L. Groat, D. Wang. Architectural Research Methods, New York, Wiley, 2002

[3] A. Anvar. Preface, In: Norouzi Talab, H.R. (ed.) Tehran (Past \& Present): The Heritage of Old Tehran, Tehran, Yassavoli Publications, 12-40, 2011.

[4] M. Hamidi et al. Structure of Tehran, Tehran, Technical and Engineering Consulting Organization of Tehran, 1997.

[5] M. Behzadfar. Case-Study: Tehran, The Identity of City, Tehran, Nashr-e-Shahr, 2007.

[6] A. Banimasoud. Iranian Contemporary Architecture, 2nd edn., Tehran, Honar-e-Memari-e-Gharn, 2009.

[7] ISNA News. The Proportion of the Capital (Tehran) in Population of Iran, Online available from https://www.isna.ir/news/93021007033/56, 2014.

[8] Statistical Centre of Iran. General Information of Tehran Province in 2017, Statistical Centre of Iran - Management and Planning Organization, Online available from http://www.mpoes.ir/Dorsapax/userfiles/Sub1/g_sarshoma r i95.pdf, 2017.

[9] Z. Qazvini (Zakaria Ben Mohhamd Ben Mahmud). Issues of Lands and News of People (أثار البلاد و اخبار العباد) Translated from Arabic to Persian by J. Mirza Qajar, and Revised and Complemented by M.H. Mohaddes (1994), Tehran, Amir Kabir, 1275.

[10] S. Sadvandian. The Story of Modernity in Iran, Institute for Iranian Contemporary Historical Studies - The Section about Transformation of Tehran, Online available from http://www.iichs.ir/News-1/(1), 2014.

[11] M. Behzadfar. Case-Study: Tehran, The Identity of City, Tehran, Nashr-e-Shahr, 2007.

[12] M. Hamidi et al. Structure of Tehran, Tehran, Technical and
Engineering Consulting Organization of Tehran, 1997.

[13] Municipality of Tehran. Living in Tehran: The Environment, Online available fromhttp://www.tehran.ir/Default.aspx?ta bid=118, 2011 .

[14] Tehran Municipality Information \& Communication Technology Organization. Atlas of Tehran Metropolis, Tehran, Tehran Municipality Information \& Communication Technology Organization, 2011.

[15] Ministry of Roads and Urban Development of Iran and Urbanism and Architecture Committee (Ministry of Housing and Urban Development). Strategic-Structural Plan of Tehran and the Development (Comprehensive Plan of Tehran in 2007), Online available from http://shahrsazi.tehran.ir/Portals/0/Documents/sanad\%20ja me1386.pdf, 2007.

[16] Tehran Disaster Mitigation and Management Organization (TDMMO) (affiliated to Municipality of Tehran). Mountaineering Paths of the North Tehran, Online available fromhttp://tdmmo.tehran.ir/Default.aspx?tabid=146\&Artic leCat egory $=156 \&$ smid $=531,2014$.

[17] Municipality of Tehran. Living in Tehran: About Tehran, Online available fromhttp://www.tehran.ir/Default.aspx?ta bid=117, 2015.

[18] G. Pasban Hazrat. River-valleys of the cities in Iran: A context of integration of human beings, city and nature, Iranian Journal of Architecture and Urbanism, Vols.58-59 No.9, 56-61, 2000.

[19] M. A. Mirfendreski et al. Proposed Project Report for Revival of Alborz (Koohsaran) Valleys in Tehran Metropolis, Tehran, Municipality of Tehran, 1995.

[20] Google Maps. Tehran, Iran (detail) Map, Google Maps, Online available from https://www.google.co.uk/maps/ @35.6835556,51.3790918, 11z, 2016.

[21] Municipality of Tehran. The Map of 22 Districts of Tehran, Online available from http://region13.tehran.ir/portals/0/Te st/tehran-map-naghshe-iran-mantaghe-shahrdary.png, 2013.

[22] Municipality of district 1 of Tehran. About the District One of Tehran: Introduction, History and Features. Online available from http://region1.tehran.ir/ Default.aspx?tabid=150, 2011 .

[23] Municipality of district 2 of Tehran. Civil and the Development Projects of the District Two of Tehran, Online available from http://region2.tehran.ir/Default.aspx?tabid= 401, 2012.

[24] M. Akbari. Explanation of Dar Abad Quarter in District One of Tehran, Online available from http://darabad.mytehran.i r/portals/0112/documents/ darabad .pdf, 2010.

[25] M. Sotoudeh. Historic Geography of Shemiran, Tehran, Cultural Research and Studies Organization of Iran, 1992.

[26] A. Rezaie. Ten Thousand Years of History of Iran, 4th edn., Tehran, Eghbal, 1993.

[27] A. A. Shamim. Iran in the Time of Qajar Monarchy, Tehran, Ebn-e-Sina, 1963. 
[28] Municipality of district 2 of Tehran. About the District Two of Tehran, Online available from:http://region2.tehran.ir/D efault.aspx? tabid=534, 2013.

[29] M. R. Farzad Behtash et al. Consideration of Farahzad river-valley (before and after organization), Danesh Shahr: Journal of Planning and Studies Organization of Tehran, Vol.15, 1-40, 2010.

[30] Google Maps. Tehran, Iran (detail) Map, Online available from https://www.google.co.uk/maps/@35.6835556,51.37 $90918,11 z, 2011$.

[31] Municipality of district 22 of Tehran. Principal Projects of the District twenty-two of Tehran: Parks and Green Areas, Online available from:http://region22.tehran.ir/Default.asp x?tabid=110, 2012.

[32] A. Madanipour. Public and Private Spaces of the City, London, Routledge, 2003.

[33] P. Bell et al. Environmental Psychology, Fort Worth, Harcourt Brace College Publishers, 1996.

[34] R. Mann. Rivers in the City, Newton Abbot, David and Charles, 1973.

[35] S. J. Craig-Smith, M. Fagence (eds.). Recreation and Tourism as a Catalyst for Urban Waterfront Redevelopment: An International Survey, Westport, London, Praeger, 1995.

[36] L. Lynch et al. Parameters for the River: A Prospectus for Rehabilitation of Parramatta River, Sydney, National Trust of Australia, 1976.

[37] D. Wrenn. Urban Waterfront Development, Washington, D.C., Urban Land Institute, 1983.

[38] Air Quality Control Organization of Tehran (Affiliated to Municipality of Tehran). The Annual Reports of Air Quality of Tehran since 2011, Online available from http://air.tehran.ir/Default.aspx?tabid=471, 2015.

[39] C. G. Boone, A. Modarres. City and Environment. Philadelphia, Temple University Press, 2006.

[40] . R. Short. Urban Theory: A Critical Assessment. Basingstoke, Palgrave Macmillan, 2006.

[41] Tehran GIS Centre. Studies of Flood, Shahrnegar: An Iranian ournal of Urban Planning and GIS, 6th year (36), 94-97, 2006.

[42] Baft Shahr Consulting Firm. Urban-Environmental Design of Velenjak River-Valley (Design Project edn), Tehran, Baft Shahr Consulting Firm in cooperation with Municipality of district 1 of Tehran, 2004.

[43] M. Nouri Sepehr. Necessity of medical waste management, Waste Management Journal, Vol.2, 12-17, 2002.

[44] M. Majlesi et al. Consideration of medical waste management in the hospitals related to Shahid Beheshti University, Research Journal of Medical Science Faculty of Shahid Behshti University, Vol.4, 299-311, 2005.

[45] M. Carmona et al. Public Places - Urban Spaces: The Dimensions of Urban Design, Oxford, Architectural Press, 2003.

[46] Mehr News Agency. Inauguration of a New City's Icon: Pole-Tabiat in Tehran, Online available from http://www.mehrnews.com/news/2387645/, 2015.

[47] Citypedia of Iran Group. Introduction of Pol-e-Tabiat in Tehran (in Natural Attractions of Tehran), Online available fromhttp://www.citypedia.ir/2014

[48] S. K. Dehghan. Take it to the Bridge: The Tehran Architect Striking the Right Chord in Iran and Beyond by The Guardian, Online available from:http://www.theguardian.c om/world/2015/ apr/20/bridge-tehran-architect-iran-leila-araghian-tabiatsanctions-iranian-designers, 2015.

[49] W. Dechau. Seven Bridges by Jurg Conzett, Zurich, Scheidegger \& Spiess, 2013.

[50] W. Dechau. Landscape Planning on a Scale of 1:1: Trutg dil Flem (Flem Riverside Trail): Seven Footbridges through a Wild Landscape in Switzerland, Topos: European Landscape Magazine, Vol.86, 62-70, 2014.

[51] J. Pakzad. Design Guide Book for Urban Spaces of Iran, 3rd edn, Ministry of Housing and Urban Development (Ministry of Roads and Urban Development), Urban Planning and Architecture Vice-Directorate, Secretariat of the Urban Planning and Architecture Higher Council of Iran, 2008.

[52] C. Paumier. Creating a Vibrant City Center: Urban Design and Regeneration Principles, Washington, The Urban Land Institute, 2004

[53] M. Walzer. Public space: Pleasures and costs of urbanity. Dissent Magazine, Vol.33, No.4, 470-475, 1986. 